\title{
EL DOMINIO EPISCOPAL SOBRE EL TERRITORIO: COMPETENCIAS Y RECURSOS
}

\author{
Ramón Barenas Alonso \\ Universidad de La Rioja \\ ramon.barenas@gmail.com
}

\begin{abstract}
RESUMEN: Este trabajo analiza las bases sobre las cuales se sustentaba la articulación eclesiástica de los espacios urbanos y rurales de la Península Ibérica entre los siglos III y VIII d. C. Con la consolidación del credo cristiano como el único y oficial del Imperio, la figura episcopal se convirtió en el patrono terrenal de las ciudades y en uno de los pocos grupos sociales que salió fortalecido tras el declive del Occidente romano. Gracias a su papel como líderes espirituales, los obispos obtuvieron un creciente poderío político y socioeconómico que les permitió ejercer una suerte de dominio territorial haciendo uso de los concilios y de las sedes episcopales como órganos de gobierno eclesiástico.
\end{abstract}

Palabras clave: Obispo, sede episcopal, concilio, provincia eclesiástica, patronazgo.

\section{THE EPISCOPAL DOMAIN OVER THE TERRITORY: POWERS AND RESOURCES}

\begin{abstract}
This paper analyzes the basis on which the ecclesiastical articulation of urban and rural areas of the Iberian Peninsula was based between the third and the eighth centuries AD. With the consolidation of the Christianism as the only and official creed of all the Roman Empire, the bishop became the earthly patron of the cities and one of the few social groups who came out stronger after the decline of the Roman West Empire. Thanks to his role as spiritual leaders, the bishops obtained a growing political and socioeconomic power that allowed them to exercise a sort of territorial domain using councils and episcopal sees as organs of church government.
\end{abstract}

Keywords: Bishop, episcopal see, council, ecclesiastical province, patronage.

Recibido: 4 de Mayo de 2016

Aceptado: 6 de Julio de 2016 


\section{Introducción}

Tradicionalmente se ha venido considerando que la crisis institucional de los modelos organizativos territoriales del Imperio romano en el momento en que comenzaron a asentarse las primeras ideas cristianas en Hispania (ss. IV-V d. C.) fue resuelta mediante la adopción y adaptación de la praxis administrativa tardorromana al ordenamiento religioso cristiano ${ }^{1}$, respondiendo así a la identificación que venía dándose entre Iglesia e Imperio desde la época constantiniana². De este modo, tomando como base la división territorial de Diocleciano (284-288), la provincialidad civil se pondría al servicio de la territorialidad eclesiástica ${ }^{3}$, las diócesis episcopales se acomodarían a los términos de la jurisdicción administrativa y las ciudades y sus sedes constituirían la base organizativa de la vida religiosa y el marco físico desde el que los obispos ejercían su autoridad local.

A nivel interno, la jerarquización del aparato administrativo-político tardorromano también tuvo su correspondencia en el ámbito pastoral, pues la formación religiosa y las atribuciones litúrgicas definieron, al menos a priori, una composición graduada del clero, describiendo una suerte de cursus honorum eclesiástico al frente del gobierno religioso del territorio ${ }^{4}$. Este modelo organizativo, que tuvo desde el siglo III a la "magistratura" episcopal como máximo referente espiritual y primera potestad sobre el espacio diocesano, siempre con

1. Así lo sugiere el canon XVII del concilio de Calcedonia (451): [...] Y si alguna ciudad fuere reedificada por la autoridad imperial o si se creasen en ella en adelante empleos civiles y públicos, también deben establecerse parroquias de igual categoría. Para los concilios orienta les, TEJADA Y RAMIRO, J., Colección de cánones y de todos los concilios de la iglesia de España y de América, t. I, 1859 (para este canon, p. 174).

2. De la información aportada por los concilios de Cartago (TEJADA Y RAMIRO, J., Colección de cánones..., 1859, pp. 191 307) parece deducirse que la acomodación estructural de las provincias eclesiásticas a las civiles ya venía produciéndose en Oriente desde mediados del siglo III. VILELLA, J., "Las primacías eclesiásticas en Hispania durante el siglo IV", Polis, n 10 , 1998, p. 272.

3. FLÓREZ, E., España Sagrada, vol. IV, 1859, pp. 108 115; MANSILLA, D., "Antiguas divi siones político administrativas de España", Burgense: Collectanea Scientifica, vol. 30, n ${ }^{\circ}$, 1989, pp. 433 436. Si bien hasta la aparición de la figura metropolitana (s. V) tal vez no sea posible hablar en Hispania de la provincia como territorio administrativo eclesiástico, ya desde comienzos del siglo IV se relaciona la pertenencia a una provincia con la ordenación clerical, lo que pone en sintonía a los límites civiles con los eclesiásticos, como un primer paso en su asimilación. Concilio de Elvira (comienzos siglo IV), can. XXIV: Todos aquellos que fueron bautizados en tierra lejana, decidimos que no sean promovidos al clero, fuera de sus provincias, puesto que su vida no es conocida. Para la canonística conciliar hispana se sigue la edición española de VIVES, J., Concilios visigóticos e hispanorromanos, 1963.

4. Algunas de las bases que caracterizaron a esta "carrera eclesiástica" quedaron recogidas en la epístola enviada por el papa Siricio a Himerio de Tarraco en el 385 (Epistola Sirici Papae ad Eumerium Tarraconensem episcopum, VIII XV) y en las actas del concilio I de Braga (561, can. VI y XX) y del concilio IV de Toledo (633, can. IV y XXVIII). 
el apoyo y la asistencia ministerial y sacramental de presbíteros y diáconos, se fue diversificando con el tiempo, dando origen a distintos órdenes clericales que conformaron en los siglos VI y VII un complejo organigrama eclesiástico ${ }^{5}$.

Por todo ello, será a partir del siglo $\mathrm{V}$ d. C. cuando la consideración de un espacio territorial como civitas, tras el deterioro urbano ocasionado por las invasiones bárbaras y el final del imperio occidental, venga determinada no exclusiva pero sí principalmente por su condición como sede de un obispado. Con el paso del tiempo y la cristianización de las aristocracias fundiarias, la predicación del evangelio rebasó las fronteras urbanas y alcanzó amplias áreas rurales en villae y aldeas, dando origen a heterogéneos núcleos cristianos a impulsos de promotores tanto eclesiásticos como laicos. La diversificación de las construcciones cristianas, de los agentes que participaron en ellas y del dominio efectivo sobre las mismas amenazaron la unidad territorial ejercida por los prelados en los núcleos urbanos y ello fomentó el necesario desarrollo de una organización diocesana del espacio que funcionara como un sistema de articulación eclesiástica del territorio no regido únicamente por el obispo, pero dependiente en última instancia de él.

\section{Prerrogativas y atribuciones del episcopado}

Aunque la figura del obispo en Occidente se fue consolidando poco a poco a medida que fueron creciendo las propias comunidades religiosas, las condiciones finales del desarrollo del poder episcopal en la Antigüedad Tardía estuvieron determinadas en gran medida por la oficialización del cristianismo en época bajoimperial ${ }^{6}$. En verdad, los primeros testimonios relativos a la presencia cristiana en Hispania (s. III d. C.) nos describen a un obispado aún al margen de las estructuras institucionales del Imperio, con unas inquietudes esencialmente pastorales y unas prerrogativas de actuación centradas en el ejercicio espiritual y en la ayuda caritativa a los pobres y desamparados.

Bajo el gobierno de Constantino (324-337), sin embargo, los prelados fueron adquiriendo notables prebendas de intervención en la esfera jurídica, se beneficiaron de importantes privilegios económicos y se dieron pasos decisivos en su incorporación al aparato estatal, asumiendo funciones similares a las magistratu-

5. Isidoro de Sevilla, De ecclesiasticis officiis, Lib. II: De origine ministrorum (ed. de A. Viña yo, 2007, pp. 103 ss.). En general sobre este asunto, FERNÁNDEZ ALONSO, J., La cura pastoral en la España romanovisigoda, 1955, pp. 194201.

6. En los primeros tiempos del cristianismo, la autoridad ecuménica de los apóstoles de Jesús fue siendo paulatinamente reemplazada por la de los obispos y ya desde finales del siglo I se les reconoció en la zona oriental como líderes de sus respectivas comunidades locales, siendo ase sorados en su gobierno por el colegio de presbíteros y asistidos en sus tareas caritativas por los diáconos. FERNÁNDEZ UBIÑA, J., "Los clérigos marginados en el Concilio de Elvira y el Libellus Precum", Marginados sociales y religiosos en la Hispania tardorromana y visigótica, 2013, p. 23. 
ras públicas en ámbitos locales y cívicos, sin que ello fuera en detrimento de su tradicional papel como líderes espirituales y benefactores de los más necesita$\operatorname{dos}^{7}$. En paralelo al declive de las curias municipales a partir de la segunda mitad del siglo III como órganos de cohesión social ${ }^{8}$, los obispos comenzaron a ejercer una importante labor asistencial para con los grupos marginales y desamparados de la sociedad (peregrinos, mendigos, huérfanos, viudas, etc.). Esta labor no sólo reportó a los prelados un indudable reconocimiento social en las comunidades cristianas, sino también la obtención de pingües beneficios económicos e incluso les dio la oportunidad de promocionarse dentro de la jerarquía eclesiástica, lo que se tradujo en un notable impulso al proceso de cristianización ${ }^{9}$.

Fue a partir de entonces cuando la condición episcopal comenzó a ser anhelada por los grupos aristocráticos, que la veían como una especie de gloriosa culminación del cursus honorum político ${ }^{10}$, y admirada por las clases menos pudientes desde el instante en el que los prelados asumieron, de facto que no de iure, las clásicas funciones cívicas de patronus y defensor civitatis ${ }^{11}$. Por si fuera poco, al asumir la administración del bautismo, de la excomunión y de la reconciliación de los fieles, el obispo se definió a sí mismo como el intermediario entre Dios y las comunidades cristianas y ello le situó como la máxima autoridad jurídica e ideológica dentro de ellas ${ }^{12}$. Los obispos se tornaron de este modo en una potente autoridad tanto eclesiástica como civil con cuya colaboración tenían que contar el gobierno central y sus representantes locales a la hora de garantizar el buen funcionamiento de las instituciones políticas y el orden social en las ciudades ${ }^{13}$.

7. FERNÁNDEZ UBIÑA, J., "Privilegios episcopales y genealogía de la intolerancia cristiana en época de Constantino", Pyrenae, no 40, vol. 1, 2009, pp. 95 101; Id., "Teoría y praxis del poder episcopal en la Hispania del Bajo Imperio", Toga y Daga: Teoría y praxis de la política en Roma, 2010, pp. 326332.

8. SÁNCHEZ ALBORNOZ, C., "El gobierno de las ciudades en España del siglo V al X", La città nell'alto medioevo. Settimane di Studio del Centro Italiano di Studi sull'alto medioevo, vol. VI, 1959, pp. 359 391, quien sitúa el proceso de extinción de las curias municipales entre los siglos VI y VII.

9. FERNÁNDEZ UBIÑA, J., "Poder y corrupción en el episcopado hispano del siglo IV", Studia Histórica. Historia Antigua, n 24, 2006, pp. 166167.

10. Inocencio, Epistola ad universos episcopos in Tolosa, IV (TEJADA Y RAMIRO, J., t. II, 1859, pp. 785 786).

11. BAJO, F., "El patronato de los obispos sobre ciudades durante los siglos IV V en Hispa nia", Memorias de historia antigua, no 5, 1981, p. 204 (notas 12 16); Id., "El sistema asistencial eclesiástico occidental durante el siglo IV", Studia Historica. Historia Antigua, n 4 5, 1986 1987, pp. 189194.

12. Concilio de Elvira (comienzos siglo IV), can. XXII.

13. ROBILLARD, E. y SOTINEL, C. (eds.), L'évêque dans la cité du IVè au Vè siècle. Image et autorité, 1998; BROWN, P., Pouvoir et persuasion dans l'Antiquité tardive. Vers un Empire chrétien, 1999, pp. 127163. 
La quinta centuria trajo consigo un periodo de gran inestabilidad e importantes cambios que estimularon el surgimiento de nuevas concepciones y relaciones de poder. Así, mientras que el Imperio iba perdiendo su privilegiada posición por el debilitamiento del aparato estatal y la población hispanorromana luchaba por conservar sus prerrogativas tradicionales, los invasores bárbaros hicieron su aparición en la Península Ibérica. Esto, unido a otros conflictos internos presentes en Hispania -vascones, cántabros y astures, bagaudas, rebeliones hispanorromanas- generó una situación de enorme caos y confusión en la sociedad del momento. No obstante, frente al deterioro y empobrecimiento que padecieron algunos de los grupos políticos y sociales que habían dominado la escena pública en épocas precedentes como consecuencia de estas adversas circunstancias, el estamento episcopal cobró un extraordinario relieve y salió en gran medida beneficiado de esta desfavorable situación.

Con la entrada y posterior asentamiento de los pueblos germanos en Hispania, se puso en tela de juicio la validez organizativa del Imperio occidental y la estabilidad de la vida urbana se vio gravemente amenazada. Ante tal coyuntura, algunas ciudades, en particular aquellas situadas en enclaves donde se produjeron asentamientos germanos más o menos prolongados -véase el noroeste hispano-, fijaron su mirada, con objeto de solicitar su ayuda y dirección, en los grupos más sobresalientes de la sociedad del momento. Entre estos grupos destacaba, por su origen mayoritariamente aristocrático ${ }^{14}$, su carisma ideológico y su creciente riqueza patrimonial, la figura episcopal.

Desde el momento en el que la desintegración del régimen bajoimperial y la progresiva desaparición del tejido curial que sostenía a las ciudades resultaron inevitables, los obispos comenzaron a asumir un papel de liderazgo a la cabeza de las ciudades que les condujo a hacerse cargo de manera más o menos involuntaria de muchas de las funciones hasta entonces exclusivas de los magistrados civiles. No conviene perder de vista, con todo, que los violentos acontecimientos y la inseguridad que acompañaron a la penetración de los pueblos germanos en Hispania suscitaron las más diversas reacciones y actitudes, algunas no muy loables, entre los líderes eclesiásticos ${ }^{15}$. Pese a ello, salvo puntuales excepciones, la mayor parte del episcopado hispano permaneció al frente de sus respectivas comunidades ejerciendo una defensa no militar de las mismas, bien como embajadores diplomáticos ${ }^{16} \mathrm{o}$ bien liderando la salvaguarda de las ciudades frente al enemigo invasor y ante la progresiva desarticula-

14. Al respecto de la evolución en la condición social del episcopado, RAPP, C., Holy Bishops in Late Antiquity: the Nature of Christian Leadership in an Age of Transition, 2005, pp. 172207.

15. UBRIC, P., La iglesia en la Hispania del siglo V, 2004, pp. 57 92; BARENAS, R., "El lide razgo episcopal en las ciudades hispanas en el siglo V. León de Tarazona", Iberia, n 10, 2007, pp. 8791.

16. Concilio IV de Toledo (633), can. XXX. 
ción de los poderes cívicos ${ }^{17}$. Teniendo presente que muchos de los obispos procedían de familias pudientes ${ }^{18}$ y gracias además al patrimonio eclesiástico que éstos venían acumulando desde el siglo IV, el estamento prelaticio no tuvo grandes dificultades a la hora de desarrollar todo tipo de políticas de auxilia destinadas a suplir la falta de recursos entre la población más desfavorecida, al cuidado de los prisioneros y cautivos o en general a solventar los problemas económicos derivados de la ofensiva germana ${ }^{19}$. El obispo se convertía en estos casos en un notable potentado que velaba por el bienestar de sus ciudadanos, ya en su mayoría cristianos, y protegía a todos sus subordinados, tanto clérigos como laicos, a imagen y semejanza del antiguo patrono romano con respecto a sus clientes ${ }^{20}$.

Este liderazgo social en las ciudades no pasó inadvertido a ojos de los monarcas germanos, quienes, una vez asentados en territorio hispano, no dudaron en aliarse con el episcopado local con el objetivo de justificar su ascenso al poder y reforzar así su preeminencia política en las ciudades. A cambio, la confianza depositada por estos nuevos líderes políticos fue garantizando nuevas e importantes prerrogativas de poder a la figura episcopal que acabaron situándola en el primer plano del panorama político, social y económico peninsular. Desde ese momento, los obispos fueron asumiendo nuevas y variadas funciones "extrarreligiosas" que les llevaron a intervenir de manera más o menos activa en prácticamente todos los aspectos de la sociedad hispanorromana de la época.

Así por ejemplo, en el ámbito jurídico, más allá del rango legal otorgado a las decisiones conciliares, la integración de la audientia episcopalis en el proceso civil romano por parte de Constantino y de sus sucesores posibilitó a los

17. Gracias a la intercesión de obispos como Martín de Tours [Sulpicio Severo, Dialogi, II, 4, 5 (ed. de C. Codoñer, 1987)], Germán de Auxerre [Constancio de Lyon, Vita Germanii III, 18 (ed. de R Borius, 1965)] o Argebado de Narbona [Julián de Toledo, Historia Wambae Regis, 21 (ed. de W. Levison et alii, MGH SSRM, V, 1910, reproducido en CCSL 115, 1976, pp. 236 237)], algunos condenados consiguieron el indulto o importantes reducciones en sus penas.

18. Concilio IV de Toledo (633), can. XIX: [...] no deben ser promovidos al clero: [...] los que no saben leer. El nivel mínimo de formación exigido para el oficio episcopal propició que únicamente los miembros de las aristocracias pudieran aspirar entonces a esta dignidad.

19. Algunos ejemplos en MAYMÓ, P., "El obispo como autoridad ciudadana y las irrupcio nes germánicas en el Occidente latino durante el siglo V", Studia Ephemeridis Augustinianum, vol. 58, no 2, 1997, pp. 557 558; RAPP, C., Holy Bishops in Late Antiquity..., 2005, pp. 223 234. Con todo, si seguimos testimonios como el de Salviano (Salviano de Marsella, Ad. Ecclesiam, I, 1, 2; II, 1 2; II, 14; III, 4, 5; III, 90 91; ed. de G. Lagarrigue, 1975), los prelados que ejercieron estas funciones tutelares con sus propios medios no debieron de ser tantos como reclamaban las necesidades de la época.

20. LEPELLEY, C., "Le patronat épiscopal aux IVe et Ve siècles: continuités et ruptures avec le patronat classique", L'évêque dans la cité du IVe au Ve siècle. Image et autorité, 1988, pp. 17 33; BROWN, P., Poverty and Leadership in the Later Roman Empire, 2002, pp. 4573. 
obispos administrar justicia tanto en las causas religiosas como en las civiles (herencias, robos, casamientos, malos tratos, etc. ${ }^{21}$. Si bien ya existía una larga tradición que reconocía la potestad disciplinar de los obispos sobre clérigos y laicos en materia dogmática, sacramental y organizativa, a lo largo del siglo IV las sentencias prelaticias fueron adquirieron el mismo valor que las emitidas por los tribunales civiles y los delitos cometidos por clérigos y obispos pasaron a ser juzgados por las asambleas episcopales ${ }^{22}$. La consideración que desde la esfera política se tuvo sobre la capacidad de juicio y la imparcialidad del episcopado en materia civil ${ }^{23}$ tuvo continuidad e incluso se potenció en el mundo hispanogodo. A lo largo de este periodo los obispos pudieron actuar a modo de ministros de justicia en cuestiones tanto religiosas como civiles e incluso en delitos de alta traición, bien solos o bien en comunión con los jueces seculares, pero siempre con la autoridad delegada del monarca. En esta época se les reconoció incluso un cierto derecho de supervisión sobre la actividad legal de los jueces laicos ${ }^{24}$, lo que elevó a los prelados hasta un escalafón inmediatamente inferior al de éstos, como una especie de jueces de segunda instancia con prerrogativas de excomunión sobre cualquier tipo de delito civil ${ }^{25}$.

En el plano administrativo-fiscal, su participación en el nombramiento de cargos civiles como los de defensor civitatis o numerarius ${ }^{26}$, sus prerrogativas en el mantenimiento de las infraestructuras cívicas ${ }^{27}$ y en la inspección de los espacios carcelarios ${ }^{28}$, o el control ejercido sobre la actividad de funcionarios estatales y gobernadores provinciales ${ }^{29}$ son hechos que confirmarían la relevancia administrativa adquirida por el episcopado a lo largo de esta época. Se observa,

21. CTh. I, 27, 1 (318) y 2 (408); ed. de P. Krueger, T. Mommsen y P. M. Meyer. CIMMA, M. R., L'episcopalis audientia nelle costituzioni imperiali da Costantino a Giustiniano, 1989.

22. CTh. XVI, 2, 12 (355); CTh. XVI, 2, 41 (412); CTh. XVI, 2, 47 (425).

23. Para el emperador Constantino, "los sacerdotes de Dios merecían más crédito que cualquier juez". Eusebio de Cesarea, Vita Constantini, IV, 27, 2 (ed. de M. Gurruchaga, 1994, pp. $353354)$.

24. Concilio III de Toledo (589), can. XVIII.

25. Concilio I de Toledo (400), can. XI; Concilio de Tarragona (516), can. IV y X; Concilio III de Toledo (589), can. XIII y XVII; Concilio I de Sevilla (590), can. III; Concilio IV de Toledo (633), can. XXXI XXXII; Concilio de Mérida (666), can. XV; Concilio III de Braga (675), can. VI; Concilio XIII de Toledo (683), can. II; Concilio XVI de Toledo (693), can. II. GONZÁLEZ, T., "La iglesia desde la conversión de Recaredo hasta la invasión árabe", Historia de la iglesia en España, tomo I, 1979, pp. 504527.

26. Código Justiniano, I.55.8 (ed. de P. Krueger, Corpus Iuris Civilis, vol. II, 1906); Lex Visigothorum, XII.1.2. (ed. de K. Zeumer, MGH. Leges, vol. 1, 1902).

27. Una inscripción emeritense alude a la actuación conjunta del dux Salla y el obispo Zenón en la restauración del puente y las murallas de la ciudad. VIVES, J., Inscripciones cristianas de la España romana y visigoda, 1969, pp. 126127 (n³63).

28. CTh. IX, 3, 7 (409); Cod. Just., IX, 4, 6 (529).

29. Cod. Just., I.4.22, 24, 2627,3031 y 33. 
por tanto, que el traslado efectivo de las tradicionales competencias de las curias a los prelados locales también en materia fiscal y tributaria convirtió a estos últimos en los nuevos referentes al frente de las ciudades en su papel de intermediarios entre los espacios locales y el poder político central ${ }^{30}$.

La autoridad y el prestigio adquirido por los obispos en esta época no descansaron únicamente en el desempeño de funciones de carácter político y jurídico, sino también en la acumulación y disfrute de unos patrimonios eclesiásticos en continuo incremento ${ }^{31}$. Desde que Constantino en el siglo IV otorgase entidad jurídica a la Iglesia y favoreciese económicamente al episcopado otorgándole la capacidad de tener propiedades así como de recibir herencias y donaciones de todo tipo ${ }^{32}$, amén de otros privilegios fiscales ${ }^{33}$, el patrimonio eclesiástico fue creciendo a un ritmo vertiginoso. A ello también contribuyeron las donaciones imperiales y privadas, los ingresos derivados del culto a las reliquias martiriales, de las ofrendas y oblaciones de los creyentes o de la realización de ciertos rituales (ordenaciones clericales, concesión del crisma o consagración de basílicas ${ }^{34}$ ), así como las rentas obtenidas por los terrenos de las iglesias urbanas y rurales que los obispos administraban ${ }^{35}$. Si bien es cierto que el reparto de las rentas eclesiales para el sostenimiento del clero, las necesidades de la escuela episcopal, la reparación de templos y las obras de caridad habrían de limitar en gran parte la concentración de grandes riquezas en manos del obispo ${ }^{36}$, la administración de los bienes eclesiásticos de la iglesia catedral, de las iglesias urbanas menores, de los martirya o del palacio episcopal y sus respectivos terrenos aseguró a los prelados el disfrute de considerables fortunas en las ciudades. Como poseedores de un patrimonio eclesiástico ina-

30. PÉREZ SÁNCHEZ, D., "Las transformaciones de la Antigüedad Tardía en la Península Ibérica: iglesia y fiscalidad en la sociedad visigoda", Studia Historica. Historia Antigua, n 17 , 1999, pp. 299318.

31. Como acertadamente describió el profesor Teja, el obispo fue un sujeto "poliédrico", pues según el punto de vista del observador puede aparecer como un sacerdote, un político, un rétor, un jurista o un juez, pero el resultado final es una conjunción de todas estas figuras. TEJA, R., Emperadores, obispos, monjes y mujeres: protagonistas del cristianismo antiguo, 1999, p. 75.

32. CTh. XVI, 2, 4 (321); CTh. XVI, 2, 28 (390).

33. Como, por ejemplo, la facultad de conservar los bienes que se poseían antes de ser obis po [CTh. XII, 1, 49 (361)] o la exención de toda prestación personal, así como de los deberes de la curia, de los impuestos sobre la industria y el comercio o de los trabajos en vías públicas y puentes [CTh. XVI, 2, 23 (319 320); CTh. XVI, 2, 810 (343, 346 y 353); CTh. XVI, 2, 40 (412)]. MARTíNEZ DÍEZ, G., "El patrimonio eclesiástico en la Hispania visigoda", Miscellanea Comillas, $\mathrm{n}^{\circ} 32,1959$, pp. 174 ss.

34. Concilio de Braga II (572), can. III VI.

35. Concilio de Tarragona (516), can. VIII; Concilio de Braga I (561), can. VII; Concilio IX de Toledo (655), can. VI; Concilio de Mérida (666), can. XVI; Concilio XVI de Toledo (693), can. V.

36. Concilio de Orleans (511), can. X y XI; Concilio I de Braga (563), can. VII. 
lienable ${ }^{37}$, los obispos adquirieron una potestad económica tal que la silla prelaticia se convirtió en un codiciado objeto de deseo por parte de familias aristocráticas locales, quienes vieron en la Iglesia el mejor modo de seguir detentando las dispensas de poder y la dignidad civil que el decadente Imperio ya no les permitía asumir ${ }^{38}$. De este modo, la equiparación cada vez mayor entre cargos eclesiásticos y magistraturas cívicas y el continuo enriquecimiento de la clase episcopal terminaron por trasladar las irregularidades y las corruptelas de una esfera a otra. Ello provocó el desarrollo de internas luchas de poder por la obtención del poder episcopal y el control sobre sus sedes, lo que convirtió al dinero, al poder o a la influencia social en moneda de cambio habitual a la hora de acceder a un cargo eclesiástico o de designar a un nuevo obispo en la $\operatorname{ciudad}^{39}$.

El poderío económico alcanzado por el obispado a lo largo de estas centurias gracias, entre otros aspectos, a su papel de administrador del patrimonio de todas las iglesias de su diócesis sirvió además como base del control prelaticio sobre el territorio circundante ${ }^{40}$. La consagración de toda iglesia por un prelado suponía la incorporación de los bienes del templo al patrimonio diocesano y el sometimiento de éste al derecho episcopal, pues eran los obispos quienes se encargaban de vigilar la administración de las riquezas eclesiales, designar al clero de las mismas y regular el culto y la administración de los sacramentos, con la única obligación de tener que visitarlas periódicamente. La administración de las iglesias de sus diócesis no sólo les dio acceso a la dote vinculada a su soste-

37. Concilio de Ancira (314), can. XV; Concilio IV de Cartago (398), can. XXXXII; Código Justiniano, I, 2, 14 (470); I, 2, 11 (445); I, 2, 21 (529); Concilio de Agde (506), can. VII, XXII y LIII; Concilio II de Orleans (538), can. XIII; Concilio II de Toledo (531), can. IV; Concilio de Léri da (546), can. XVI; Concilio de Braga II (572), can. XIV XVII; Concilio III de Toledo (589), can. III IV y XIX; Concilio IV de Toledo (633), can. LXVII; Concilio VI de Toledo (638), can. XV.

38. MATHISEN, R. W., Roman Aristocrats in Barbarian Gaul. Strategies for survival in an age of transition, 1993, pp. 89 104. No en vano, la mayoría de los obispos de la época parecen pro ceder de las elites aristocráticas. FERNÁNDEZ UBIÑA, J., "La iglesia y la formación de la jerar quía eclesiástica", La Hispania del siglo IV. Administración, economía, sociedad, cristianización, 2002, pp. 161203.

39. FERNÁNDEZ UBIÑA, J., "Poder y corrupción...", 2006, pp. 161 184; CASTILLO MAL DONADO, P., "In ecclesia contra ecclesiam. Algunos ejemplos de disputas, violencias y faccio nes clericales en las iglesias tardoantiguas hispanas", Antiquité Tardive, n 15, 2007, pp. 263 274; Id., "Corrupción y luchas orgánicas en las iglesias visigóticas", La corrupción en el mundo romano, 2008, pp. 381 392; UBRIC, P., "Corrupción, ambición e indisciplina en la Igle sia hispana del siglo V", La corrupción en el mundo romano, 2008, pp. 355369 . Esta situación fue denunciada por la propia Iglesia en su época. Eusebio, Vita Constantini IV, 54, 2 (ed. de M. Gurruchaga, 1994, p. 377); Concilio de Sérdica (344), can. VIII.

40. ZICHE, H. G., "Administrer la propriété de l'église: l'évêque comme clerc et comme entrepreneur", Antiquité Tardive, no 14, 2006, pp. 69 78; MARTIN, C., "Les évêques visigothi ques dans leur espace: de l'autonomie à l'intégration", Les élites et leur espace : mobilité, rayonnement, domination (Vle-Xle ss.), 2007, pp. 210211. 
nimiento sino también al personal encargado de su gobierno y cuidado ${ }^{41}$, lo que en un ámbito socioeconómico determinó un control más o menos firme sobre estas iglesias y en un plano físico condicionó la extensión efectiva de la jurisdicción de su diócesis ${ }^{42}$. En este sentido, todas las iglesias no monásticas que se iban fundando fuera de la ciudad -en vici, villae, castelli u otros núcleos menores-, y que eran consagradas por los prelados del territorio correspondiente, así como parte de sus rentas, pasaban a depender jurisdiccionalmente del episcopado. Así, pese a las denuncias ${ }^{43}$, los obispos dispusieron del patrimonio de las iglesias y del personal dependiente de ellas en calidad de propietarios comunes, estableciéndose una línea de separación muy difusa entre los bienes personales del obispo y los bienes pertenecientes a la Iglesia como entidad.

Más allá de la controversia que suscitó esta actitud, el mayor problema vino dado cuando las elites locales comenzaron a erigir iglesias privadas y monasterios en sus propiedades rurales, dentro de territorios pertenecientes a ciudades con o sin obispo, lo que acarreó grandes trabas a la extensión de las jurisdicciones prelaticias, máxime cuando algunos fundadores intentaron establecer una propiedad privativa y definieron una autonomía patrimonial de sus espacios de culto con respecto al dominio episcopal ${ }^{44}$.

En lo relativo a la ámbito social, a partir del momento en el que los nobles hispanos tomaron conciencia de que tras las invasiones germanas el Estado romano era incapaz ya de garantizarles su preeminencia en la sociedad o de asegurarles una promoción en su carrera política, la dignitas eclesiástica se convirtió en la meta a alcanzar por todos aquellos que buscaban mantener un status social elevado a nivel local ${ }^{45}$. La progresiva aristocratización del episcopado a lo largo de los siglos IV y $\mathrm{V}$ fue introduciendo ciertos hábitos propios de la tradicional nobilitas romana como el patronato cívico. Si bien en manos de los obispos el evergetismo no perdió su clásico tono de autoglorificación y su significación centralizadora, ahora sin embargo su campo de actuación se hizo extensivo a toda la población de la ciudad y alrededores

41. Al respecto de la dominación episcopal sobre el clero de las iglesias, Concilio de Méri da (666), can. XII XIII, XVII y XXI. Sobre los serui y liberti adscritos al control prelaticio, Con cilio de Agde (506), can. XLIX y LXII; Concilio III de Toledo (589), can. VI; Concilio IV de To ledo (633), can. LXVII LXVIII y LXXIV; Concilio VI de Toledo (638), can. IX; Concilio IX de Tole do (655), can. XI XIII.

42. Concilio de Orange (411), can. X: Concilio III de Toledo (589), can. IX, can. XIX; Con cilio IV de Toledo (633), can. XXXV.

43. Concilio III de Braga (675), can. VIII: Pues corre por ahí la opinión de que ciertos obispos explotan a los siervos de la iglesia en sus propios trabajos, aumentando las rentas de su hacienda propia, pero causando perjuicios a los bienes del Señor.

44. Concilio de Lérida (546), can. III; Concilio III de Toledo (589), can. IV.

45. PRIETO, M., Los obispos hispanos a fines del Imperio romano (ss. IV-VI). El nacimiento de una elite social, 1994, pp. 5276. 
sin excepciones ${ }^{46}$ y derivó sus intereses inversores hacia otros objetivos. En tanto que nuevos "magistrados municipales", los prelados dedicaron gran parte de sus recursos económicos al embellecimiento de sus ciudades y acabaron rivalizando unos con otros en la construcción y ampliación en este caso de majestuosos edificios de culto en los que se dejaba constancia mediante laudatorias inscripciones de la magnanimidad de sus fundadores hacia los pobres y desamparados. Testimonios de carácter epigráfico como los epitafios de Justiniano de Valencia o Juan y Sergio de Tarraco ${ }^{47}$, u otros de índole literaria como los textos de las Vitas Sanctorum Patrum Emeretensium relativos a los obispos Fidel, Masona y Renovato $^{48}$ son una muestra clara de las actividades edilicias emprendidas por los prelados en sus respectivas urbes así como de la labor asistencial que éstos ejercían en apoyo, consuelo y protección de peregrinos, viudas, huérfanos, enfermos, cautivos y menesterosos en general.

Toda esta encomiable labor, más allá de un componente humanitario y de una funcionalidad panegirista, tuvo también un claro trasfondo de control socioeconómico del territorio desde el momento en el que la creación de núcleos religiosos o asistenciales, en torno a los cuales se congregaban diferentes grupos humanos y a partir de los cuales se obtenían una serie de beneficios económicos, implicaba la extensión de la autoridad episcopal sobre todos ellos y, por ende, sobre el espacio que éstos ocupaban. Se establecía entonces una especie de relación patronal o clientelar entre los obispos, quienes ofrecían determinados bienes y servicios litúrgicos, asistenciales o educativos a la comunidad, y los fieles, que a cambio de ello reconocían públicamente el honor prelaticio mediante el encargo de inscripciones laudatorias o de estatuas en su memoria, la concesión de cargos honoríficos o la reserva de un lugar privilegiado en las reuniones con su grey ${ }^{49}$. En este sentido, el hecho que toda la población tanto urbana como rural que contase con menos recursos pudiera acudir hasta la ciu-

46. VSPE V, III: [Masona] Después edificó un hospital y lo enriqueció con un gran patrimonio, equipándolo con sirvientes y médicos; mandó que se atendieran las necesidades de los peregrinos y enfermos y dio orden de que los médicos, recorriendo sin cesar los alrededores de toda la ciudad, llevaran en brazos al hospital a cualquiera que, siervo o libre, cristiano o judío, encontraran enfermo (ed. de I. Velázquez, 2008, p. 89). LEPELLEY, C., "Le patronat épiscopal...", 1998, pp. 1920 y 2933.

47. VIVES, J., Inscripciones cristianas..., 1969, pp. 8385 y 123, no 277 (Juan), 278 (Sergio) y 356 (Justiniano); ALFÖLDY, G., Die Römischen Inschriften von Tarraco, 1975, n 938 (Juan) y 939 (Sergio); FITÁ, F., "Epigrafía cristiana de España”, BRAH, no 37, 1900, pp. 510515.

48. VSPE IV, X, 23 (Fidel); V, III (Masona); V, XIV (Renovato). Sobre la imagen totalmente pro pagandística del episcopado en esta obra, VELÁZQUEZ, I., La literatura hagiográfica. Presupuestos básicos y aproximación a sus manifestaciones en la Hispania visigoda, 2007, pp. 253257.

49. FUENTES HINOJO, P., "Patrocinio eclesiástico, rituales de poder e historia urbana en la His pania Tardoantigua (siglos IV al VI)", Studia Historica. Historia Antigua, no 26, 2008, pp. 316317. 
dad para solicitar un sustento alimenticio ${ }^{50}$ no ha de entenderse sólo en términos de labor asistencial sino también como un claro indicio del radio de influencia episcopal por el territorio diocesano ${ }^{51}$.

Durante los primeros siglos de afianzamiento del cristianismo el liderazgo espiritual sobre las ciudades había sido ejercido por la figura martirial. En calidad de intermediarios entre la esfera celestial y la terrenal, los mártires fueron designados desde el siglo IV como patronos espirituales de las ciudades con un poder y una influencia en la corte celeste similar a la ejercida hasta entonces por los patronos cívicos. Ante este hecho, los obispos no tardaron en convertirse en auténticos "empresarios de su culto"52, haciéndose cargo de todo el ceremonial que rodeaba a los mártires, sobre todo tras su muerte.

El control del sepulcro y del traslado de reliquias, la organización de procesiones, la redacción y lectura pública de las passiones, la construcción de basílicas en su honor, la conmemoración de sus aniversarios portando las reliquias martiriales al cuello $^{53}$, etc.; todos estos elementos contribuyeron a reforzar la cohesión social y a legitimar el gobierno efectivo del obispo en la urbe. Si los mártires se habían convertido en los patronos y defensores divinos de las ciudades, los obispos, como instigadores en muchos casos de la devoción hacia ellos, se definieron ahora como los representantes terrenales del poder celeste ejercido por ellos, beneficiándose indirectamente de todo el aparato económico generado por el culto a sus reliquias ${ }^{54} \mathrm{y}$ asumiendo con el tiempo en su propia figura el rol de protectores y patronos de sus respectivos núcleos urbanos.

Con la asimilación cada vez mayor entre obispos y mártires como patronos de sus respectivas urbes, la historia de la ciudad quedó enteramente ligada a la de sus líderes eclesiásticos y su vida cotidiana comenzó a desarrollarse en función de los diversos actos de la vida institucional y la simbología ritual del obis$\mathrm{po}^{55}$. Desde su triunfal entrada en la ciudad (adventus $)^{56}$ hasta la deposición de

50. VSPE V, III 7.

51. En función del número de kilómetros que se pueden recorrer a una media jornada de distancia de la ciudad, C. Martin calcula que el radio de influencia de la sede episcopal podría alcanzar unas 15 millas a su alrededor. MARTIN, C., La géographie du pouvoir dans I 'Espagne visigothique, 2003, p. 113.

52. BROWN, P., The cult of the saints: its rise and function in latin christianity, 1982, p. 90.

53. Concilio III de Braga (675), can. V: [...] supimos, en efecto, que en las solemnidades de los mártires, dirigiéndose a la iglesia, se ponen al cuello algunas reliquias, y para hincharse delante de los hombres con una gloria más fastuosa, como si ellos fueran el arca de las reliquias [...].

54. Al respecto de los beneficios económicos reportados por este culto, BUENACASA, C., "La instrumentalización económica del culto a las reliquias: una importante fuente de ingresos para las iglesias tardoantiguas occidentales (ss. IV VIII)", Santos, obispos y reliquias, 2003, pp. 123140.

55. FUENTES HINOJO, P., "Patrocinio eclesiástico, rituales de poder...", 2008, pp. 330336.

56. VSPE V, 8, 8 17. FUENTES HINOJO, P., "Adventus praesulis: consenso social y rituales de poder en el mundo urbano de la Antigüedad Tardía", Studia Historica. Historia antigua, $\mathrm{n}^{\circ}$ 29, 2011, pp. 294333. 
sus restos, habitualmente en la basílica del santo patrón de la ciudad ${ }^{57}$, acompañada de exequias y duelos públicos, todos estos actos suponían una clara manifestación de la magnificencia y el liderazgo social que el obispo ejercía sobre su propia comunidad. La asimilación entre obispos y mártires fue tal que ambos acabaron adoptando las mismas prerrogativas celestiales sobre la ciudad, adquiriendo similares virtudes de santidad y generando en torno a ellos todo un ceremonial de devoción y culto que ordenó la vida litúrgica de las ciudades ${ }^{58}$.

El auge del fenómeno ascético entre los siglos $V$ y VI, por su parte, determinó un traslado de la santidad de los mártires hacia la figura del asceta, eremita o anacoreta, cuya vida de renuncia y mortificación se vio equiparada a la de aquellos que padecieron martirio o dieron su vida por la fe en Cristo entre los siglos III y IV. Asumiendo el creciente prestigio social adquirido por estos "nuevos" religiosos, los obispos no dudaron en adoptar hacia ellos una actitud similar a la mostrada con los mártires en su momento y haciendo uso, por ejemplo, del elemento hagiográfico, se convirtieron en auténticos capitalizadores de su culto. Uno de los mejores testimonios de ello lo tenemos en la figura de Braulio de Zaragoza quien compuso la Vita Sancti Aemiliani como una suerte de himno en honor al eremita riojano con objeto de ser leído en la misa del santo ${ }^{59}$. Con el tiempo, los obispos acabaron protagonizando sus propias Vitae, lo que sirvió a los prelados que las redactaron para enaltecer las figuras de sus predecesores o las de sí mismos y sus sucesores como miembros todos de la misma sacrosanta estirpe ${ }^{60}$.

La civitas se convirtió, en definitiva, en el escenario de la apoteosis episcopal, teniendo ésta como bases el creciente enriquecimiento económico, el prestigio social por su labor caritativa, el dominio ideológico sobre el culto a mártires y santos y su cada vez mayor protagonismo en la esfera política. Los obispos, en tanto que dirigentes religiosos y miembros de un grupo socioeconómicamente favorecido, fueron reconocidos a modo de autoridades locales en

57. Valgan como ejemplo los obispos emeritenses, cuyos restos fueron depositados en la basí lica de Santa Eulalia [VSPE, IV.4.8 (Paulo), V.13.8 15 (Masona) y X.1 9 (Fidel)]. Sobre todo el pro ceso ritual en torno a los últimos momentos de vida del obispo y en los instantes inmediatamente posteriores a su óbito, CASTILLO MALDONADO, P., "In hora mortis: deceso, duelo, rapiña y lega do en la muerte del obispo visigótico", Hispania Sacra, vol. 64, n 129, 2012, pp. 1017.

58. VSPE V, III, 12: Cuando se dirigía (el obispo Masona) en procesión a la iglesia, muchos niños vistiendo capas de seda pura caminaban delante de él, como ante un rey, cosa que en este tiempo nadie podía ni se atrevía a hacer, y ataviados con tales indumentarias, avanzando hacia él, le rendían el homenaje debido (2008, p. 90).

59. Braulio de Zaragoza, Vita Sancti Aemiliani, Introducción: Y en torno a ello dicté como pude y en lenguaje Ilano y claro [...] un librito sobre la vida de este santo; preparé una redacción breve de modo que pueda ser leído en la misa de su celebración rápidamente [...]. Ed. de P. Ortiz, "San Braulio, la vida de San Millán y la Hispania visigoda del siglo VII", Hispania Sacra, no 45,1993 , p. 474.

60. Ejemplos de ello serían las VSPE en Mérida o el de Viris Illustribus de Ildefonso para Tole do (ed. de C. Codoñer, 1972). 
sus respectivas zonas y ejercieron un patronazgo cívico con una autonomía de decisión sobre asuntos de índole político-legislativa nunca antes alcanzada por parte de las tradicionales curias romanas.

Para poder ejercer un dominio eclesiástico sobre la ciudad y el territorio bajo su jurisdicción diocesana, el obispo no sólo se valió de su condición de clase privilegiada y de su poderío económico al frente de las ciudades. Tras el final del dominio romano en Occidente y una vez asentados los pueblos bárbaros en la Península, el episcopado llevó a cabo una cuidada estrategia de colaboracionismo con la monarquía germana, en especial con la visigoda, que le reportó una destacada parcela de participación en la vida política del momento. La efectividad de ésta y el consecuente control territorial fueron posibles, entre otros factores, gracias al uso de dos instrumentos clave en la fijación del dominio territorial prelaticio: el concilio eclesiástico y la sede episcopal.

\section{Instrumentos de gobierno episcopal}

El gobierno prelaticio de la diócesis estaba regulado por la legislación conciliar, cuyo cumplimiento, tanto a nivel provincial como general, era obligatorio para todo el personal eclesiástico ${ }^{61}$. La potestad individual de cada obispo quedaba así limitada por la autoridad superior que a lo largo del siglo IV fueron asumiendo los concilios ecuménicos y regionales. La efectividad de este corpus legal venía determinada, a su vez, por la intervención del emperador, quien desde los tiempos de Constantino dictaminaba leyes civiles en paralelo a las conciliares o dotaba a éstas últimas con rango de ley, obligando a que los acuerdos que se tomaban en las asambleas conciliares fuesen acatados tanto por las instituciones eclesiásticas como por los jueces y gobernadores civiles provinciales ${ }^{62}$.

La aplicación de esta normativa se realizaba, por su parte, desde el marco de las sedes episcopales, principal sede de gobierno de los prelados desde donde ejercían a su vez el control eclesiástico sobre el territorio dependiente de ellas.

\subsection{El concilio eclesiástico}

El principal órgano de gobierno donde los obispos llevaban a cabo una toma de decisiones de índole doctrinal y disciplinar, aunque más tarde también política, y a partir del cual emanaba el poder que éstos ejercían desde las sedes episcopales fue el concilio eclesiástico. Deudores en su configuración de las

61. La realidad fue que el incumplimiento de estas leyes únicamente reportaba castigos de índole eclesiástica excomunión, apartamiento de la sede episcopal y sólo comprometía en verdad a quienes acudían a los concilios. Concilio I de Braga (561), can, XXII; Concilio XVI de Toledo (693), can. VII.

62. Eusebio de Cesarea, Vita Constantini, 4, 27, 2 (ed. de M. de Gurruchaga, 1994). 
antiguas asambleas provinciales y de las curias municipales romanas, los concilios se convirtieron en una herramienta básica a través de la cual los prelados actuaban en representación de la ciudad y de la provincia sobre la que se asentaba su jurisdicción diocesana y participaban activamente de la vida religiosa y política de la Península Ibérica.

Si bien la celebración de periódicas reuniones sinodales ya había tenido lugar con anterioridad al siglo IV ${ }^{63}$, la concesión de libertad religiosa en el Imperio en el 313 y la política constantiniana facilitaron el desarrollo de una práctica que tras el sínodo de Nicea (325) se institucionalizó como el principal instrumento de autoridad eclesiástica sobre el territorio. Como sínodo que representaba la universalidad de la Iglesia, Nicea fue el primero de una serie de concilios ecuménicos -Nicea I (325), Constantinopla I (381), Éfeso (431), Calcedonia (451) ${ }^{64}$, Constantinopla II (553), Constantinopla III (680-681) y Nicea II (787)-, que reunieron a los principales líderes de la cristiandad del Imperio con el objetivo de alcanzar un orden tanto disciplinar como dogmático y definir un credo único y común a todos ellos para así hacer frente al creciente desarrollo de heterodoxias cristianas. Para la consecución de esta meta, el sínodo niceno estableció la necesidad de convocar nuevos y periódicos concilios provinciales en lo sucesivo y regularizó el ritmo de convocatoria de estas reuniones fijando dos fechas al año para su celebración: uno antes de la Cuaresma y otro en otoño ${ }^{65}$.

Tomando como base lo resuelto en Nicea, a partir del siglo IV se desarrolló una activa dinámica conciliar que tuvo a África, Galia e Hispania como principales escenarios, alternando circunstancialmente la proyección de sínodos entre lo provincial y lo general. Dada la acomodación de la geografía eclesiástica a la civil, la provincia se convirtió también en base de la organización religiosa terri-

63. Eusebio de Cesarea da noticia en su Historia Eclesiástica de la celebración de varios concilios en Asia Menor en los siglos II y III. Eusebio, Hist. ECl., V, 23 25; VI, 33, 43; VII, 5, 7, 2730 y X, 5. (ed. de G. Bardy, 1993, pp. 66 72, 135 136, 153 159, 168 170, 171 173, 211 220). Por su parte, en época del obispo Cipriano de Cartago (249 258) se ha documentado la celebración de al menos siete concilios en el norte de África entre los años 251 y 256 (VV. AA., Dictionnaire d'Histoire et de Géographie ecclesiastiques, t. I., 1912, cols. 747 750). Por lo que respecta al territorio hispano, el registro conciliar más antiguo que poseemos es el del Concilio de Elvira, de comienzos del siglo IV. Pese a su gran número de cánones, las exiguas menciones a la convocatoria de asambleas de este tipo, si acaso a reuniones de ámbito local (can. LIII: inter fratres y LXXIV: convento clero), sugieren que la celebración de sínodos no fue una dinámica habitual en la Hispania del siglo IV.

64. Se considera que el Concilio de Calcedonia (451) fue el que introdujo el concepto de ecumenismo al definirse a sí mismo como un sínodo universalis. TANNER, N. P., Los concilios de la lglesia: breve historia, 2003, pp. 3941.

65. Concilio de Nicea (325), can. V. Esta dualidad anual en la celebración sinodal siguió siendo recordada por el papa Hormisdas a comienzos del siglo VI. Epistolae Hormisdae papae ad episcopos per Hispaniam constitutos, III (TEJADA Y RAMIRO, J., 1859, t. II, p. 1008). 
torial. En virtud de ello, los primeros concilios occidentales fueron exclusivamente provinciales, reunidos en las capitales de las provincias bajo la presidencia de un obispo metropolitano. En la Península Ibérica, ciudades como Braga, Zaragoza, Barcelona o Sevilla se convirtieron en núcleo central de diferentes reuniones sinodales de extensión provincial entre los siglos IV y VII, si bien a lo largo de esta última centuria se fue dando paso a la consolidación del concilio "nacional" celebrado siempre en la ciudad de Toledo bajo el signo político visigodo. A este respecto, si ya el concilio II de Toledo (531), pese a ser provincial, tuvo una clara vocación generalista ${ }^{66}$ y el tercero (589) reunió a todo el episcopado hispano-galo, fue, sin embargo, el concilio IV de Toledo (633) el encargado de marcar un impasse al institucionalizar en Hispania el concilio general como una instancia jurídica superior $^{67}$ donde habrían de tratarse las principales cuestiones de fe o de interés común a todo el episcopado hispano y galo (Narbonense ${ }^{68}$. Aunque en este sínodo se insistió en la necesidad de seguir celebrando asambleas provinciales con una cierta regularidad, el progresivo centralismo de Toledo en el panorama eclesiástico hispano en detrimento de la presencia de las metrópolis periféricas y la creciente necesidad regia de legislar sobre asuntos de interés general vinculados a sus gobiernos no dejaron apenas lugar a lo particular. En verdad, a excepción del concilio emeritense (666), del III de Braga (675) y de los toledanos IX (655), XI (675) y puede que el XIV (684), no tenemos noticias de la celebración de ninguna otra asamblea provincial en Hispania durante todo el siglo VII.

Por lo que se refiere a la temporalidad en la celebración de los concilios, si bien en Nicea se estipuló la bianualidad en su convocatoria, ya fuese a causa de la difficultas temporum, por la longitudo et paupertas de las iglesias hispanas o bien a razón de la sacerdotum neglegentia, finalmente se decidió establecer el criterio anual tanto para las reuniones provinciales como para las generales ${ }^{69}$. Con todo, pese a la insistencia en la reafirmación del principio de periodicidad sinodal, el concilio eclesiástico no fue nunca una institución regular ni tuvo un ritmo de celebración uniforme durante la Antigüedad Tardía. Así, desde la celebración del Concilio III de Toledo (589) hubo de transcurrir casi medio siglo hasta que se convocó otro y aunque los sínodos toledanos a partir del IV (633) siguieron una enumeración correlativa, dos de ellos -IX (655) y XI (675)-fueron

66. CASTILLO MALDONADO, P., "Concilios hispanos tardoantiguos: de asamblea religiosa a asamblea política", Toga y daga. Teoría y praxis de la política en Roma, 2010, p. 420.

67. Esta superioridad queda patente en la apelación que el obispo Marciano de Écija realizó a los Concilios IV y VI de Toledo contra la sentencia dictada por el concilio provincial de Sevilla condenándole por al menos tres delitos que supuestamente no había cometido. La transcripción y traducción del texto, que no se conservó en la canonística oficial, en TEJADA Y RAMIRO, J., t. II, 1859, pp. 325331.

68. Concilio IV de Toledo (633), can. II III.

69. Concilio III de Toledo (589), can. XVIII; Concilio IV de Toledo (633), can. III. 
provinciales de la Cartaginense mientras que el celebrado en el 684 (XIV) tuvo una naturaleza peculiar a medio camino entre lo provincial y lo general ${ }^{70}$. De los once sínodos restantes, cuyas actas revistieron un carácter general, seis de ellos se celebraron a lo largo de un periodo de veintitrés años (633-656), al que le siguió un lapso de tiempo casi similar (657-680) durante el cual no se reunió ninguna asamblea general y a continuación otra etapa de dos décadas (681702) que dio pie a la convocatoria de seis concilios más ${ }^{71}$, aunque del último no se han conservado las actas ${ }^{72}$.

Del mismo modo, la fijación de una fecha concreta para la celebración de estos eventos tampoco obtuvo un respaldo fiel a lo largo del siglo VII pues aunque el concilio III de Toledo (589) en su canon XVIII instituyese las calendae novembrium como día de reunión episcopal, años más tarde se advirtió más adecuado elegir la estación primaveral y el mes de mayo como fecha asamblearia $^{73}$. Con el tiempo, la decisión en torno a la elección del día específico en el que habría de reunirse el concilio se dejó en manos del monarca de turno o, en su defecto, del metropolitano toledano ${ }^{74}$. Pese a que en poco más de un lustro se decidió retomar el 1 de Noviembre como día de reunión sinodal ${ }^{75}$, lo cierto es que al final no se respetó ninguna fecha fija y la celebración de los concilios hubo de oscilar en función de las circunstancias históricas concretas de cada momento y de la necesidad de legislar nuevamente en relación a ellas ${ }^{76}$.

La asistencia a estos concilios era estrictamente obligatoria para todos los prelados de la provincia si el sínodo era provincial o para todo el episcopado del reino si éste era general, salvo en situaciones de falta justificada, en cuyo caso un arcipreste, un presbítero o un diácono debía acudir a ellos en nombre del obispo ausente [Fig. 1].

En calidad de asambleas mixtas estas reuniones contaron casi desde sus inicios con presencia tanto clerical como laica ${ }^{77}$, pero fue sobre todo en época visigoda,

70. Concilio XIV de Toledo (684), can. I.

71. ORLANDIS, J. y RAMOS LISSÓN, D., Historia de los concilios de la España romana y visigoda, 1986, pp. 299507.

72. En un índice manuscrito del códice de la Hispana, hoy desparecido (MARTíNEZ DíEZ, G., La Colección Canónica Hispana, vol. I, 1966, pp. 166 167), se alude a la celebración de un Concilio XVIII de Toledo en torno a los años 702 703, bajo el reinado de Witiza, al que pudie ron acudir al menos cincuenta obispos, pero del que no se han conservado sus actas.

73. Concilio IV de Toledo (633), can. III.

74. Concilio XI de Toledo (675), can. XV.

75. Concilio XII de Toledo, 681, can. XII.

76. LETINIER Y MICHEL, R., La función judicial de los concilios hispanos en la Antigüedad Tardía, 1998, p. 21 (nota 57).

77. Concilio de Elvira (comienzos del siglo IV), praefatio; Concilio de Tarragona (516), can. XIII; Concilio IV de Toledo (633), can. IV. 


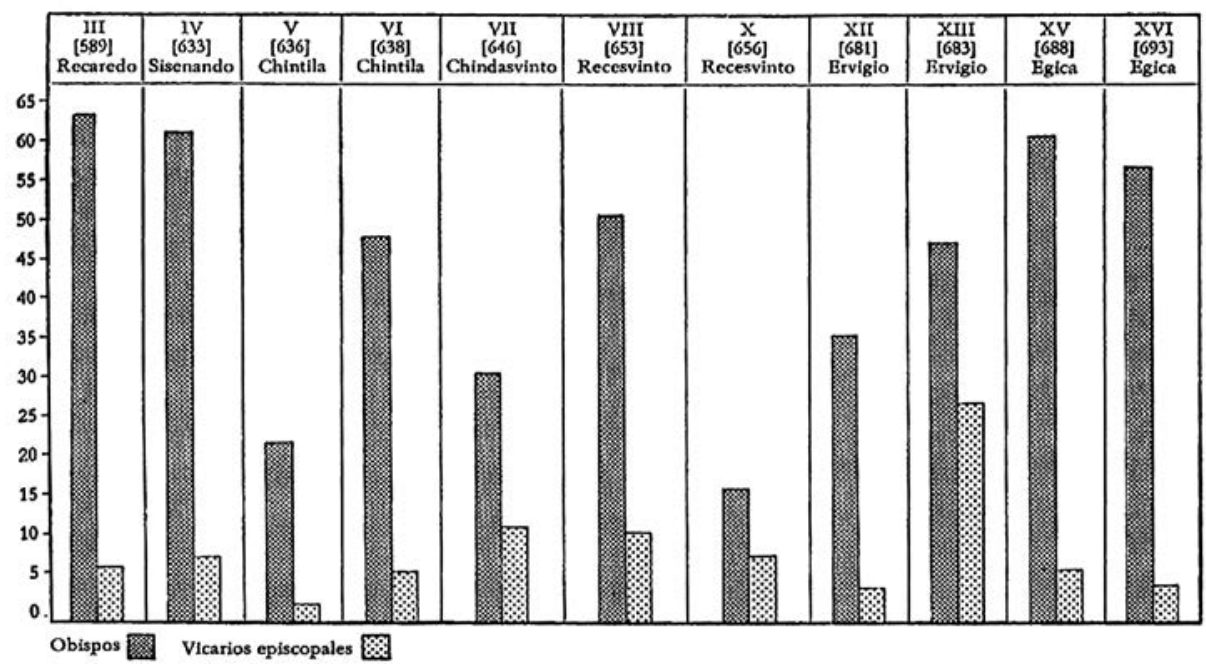

Figura 1. Representación episcopal hispana en los Concilios Generales de Toledo (ORLANDIS, J. Y RAMOS-LISSÓN, D., 1986).

debido a la participación regia, cuando los concilios se convirtieron en heterogéneos espacios de reunión en los que ya no se trataron únicamente asuntos de índole eclesiástica. Así por ejemplo, la participación de altos funcionarios civiles de la región ${ }^{78}$ determinó que los concilios legislaran también sobre cuestiones de naturaleza jurídica y económica, lo que supuso un primer paso en el reconocimiento de los efectos legales en materia civil de las resoluciones allí tomadas. Este proceso alcanzó su cénit con la fijación de la lex regia in confirmatione concilii tras las actas conciliares, impuesta por vez primera en el 589 pero sólo habitual a partir de finales del siglo VII y en particular en los concilios que trataron asuntos de calado político ${ }^{79}$. Gracias a la confirmación regia y a la vinculación de algunos de sus cánones al Liber ludiciorum ${ }^{80}$, las decisiones conciliares adquirieron fuerza de ley. Este hecho reforzó en lo político las sanciones civiles al teñirlas de un cariz de aprobación divina mientras que en lo eclesiástico otorgó un fuerte peso legal al dominio ideológico que los obispos ejercían sobre las ciudades ${ }^{81}$.

78. Concilio III de Toledo (589), can. XVIII; Concilio II de Sevilla (619), can. I.

79. ORLANDIS, J., La iglesia en la España visigótica y medieval, 1976, pp. 185 221; ORLANDIS, J., y RAMOS LISSÓN, D., Historia de los concilios..., 1986, pp. 190194.

80. Así por ejemplo los cánones del Concilio XIII de Toledo (683) fueron confirmados en el Liber Iudiciorum, en su ley XII.1.3. Del mismo modo, las leyes de Ervigio contra los judíos incluidas en el título III del libro XII de este código civil fueron aprobadas por el Concilio XII de Toledo (681), en su can. IX.

81. Concilio XII de Toledo (681), praefatio. 
A lo largo del último siglo de dominio visigodo en Hispania, la composición de los concilios toledanos se fue completando asimismo con las firmas de abades y magnates palatinos entre los registros prelaticios. Si la asistencia de abades a los procesos sinodales ya era solicitada en la Tarraconense a finales del siglo VI, por influjo probablemente galicano ${ }^{82}$, la celebración de concilios abaciales fue un fenómeno a priori exclusivamente galaico ${ }^{83}$, pues el registro de líderes monacales en un concilio general no se hizo patente hasta mediados de la siguiente centuria. Diferenciados de aquellos otros que firmaban las actas a título de vicarios prelaticios ${ }^{84}$, los abades adquirieron una entidad eclesiástica propia en los registros conciliares a partir del Concilio VIII de Toledo (653), conformando un auténtico ordo abbatum ${ }^{85}$ y ocupando un privilegiado lugar en las firmas conciliares entre los obispos y sus vicarios. El notable desarrollo del fenómeno monacal dentro y fuera de las urbes, sobradamente presente en la legislación conciliar del momento ${ }^{86}$, y el enorme prestigio socioeconómico que iban adquiriendo algunos líderes de los espacios cenobíticos en esta época fueron la base de su participación en el panorama sinodal hispanogodo desde mediados del siglo VII, ya fuese con entidad propia, representando incluso a iglesias metropolitanas ${ }^{87}, \mathrm{o}$ bien en calidad de vicarios episcopales [Fig. 1] $]^{88}$. Tal fue la vinculación entre monacato y episcopado en esta época que al tiempo que algunos ilustres obispos

82. Concilio de Huesca (598): Que todos los años cada uno de nosotros mande congregarse en el lugar que el obispo designare, a todos los abades de los monasterios, a los presbíteros y diáconos de su diócesis. A este respecto, los concilios de Tarragona (516, can. XI) y Lérida (546, can. III) remiten a los sínodos galos (Agde y Orleans principalmente) en los que, a su vez, se expuso la obligación de que los abades acudieran a sínodos anuales donde designara el obispo (Concilio I de Orleans, 511, can. XV).

83. ORLANDIS, J., "Abades y concilios en la Hispania visigótica", Antigüedad y Cristianismo, no 3, 1986, pp. 223224.

84. Concilio VII de Toledo (646): Crispín, abad, representante de Neufredo mi señor, obispo de Lisboa; Concilio VIII de Toledo (653): Osdulgo, abad de Ricimiro, obispo de la iglesia de Dumio.

85. ORLANDIS, J. y RAMOS LISSÓN, D., Historia de los concilios..., 1986, p. 178.

86. Si bien ya desde el concilio I de Zaragoza (380) se legisla sobre los monaci en relación a la extensión del priscilianismo, será a partir del siglo VI cuando el fenómeno alcance su cénit y su presencia se haga más habitual en las disposiciones conciliares, tanto hispanas [Concilio de Tarragona (516), can. XI; Concilio I de Barcelona (540), can. XI; Concilio de Lérida (546), can. III; Concilio de Valencia (549), can. V; Concilio III de Toledo (589), can. III IV] como galas [Concilio de Agde (506), can. XXVII XXVIII y LVII LVIII; Concilio de Orleans (511), can. XV y XVIII o Concilio de Epaona (517), can. V].

87. Las metrópolis de Tarragona (Argebado), Mérida (Maximus y Boniba), Braga (Recesin do), Sevilla (Gaudencio) y Narbona (Juan) se hicieron representar en el Concilio XIV de Toledo (684) por abades, lo que da una idea de la alta estima en la que se tenía en estos momentos a la condición abacial.

88. Concilio VIII de Toledo (12 abades y 1 vicario), IX (6 abades), X (2 vicarios), XI (3 abades y 5 vicarios), XII (4 abades), XIII (4 y 12), XIV (5 y 6), XV (8 y 2$),$ XVI (5 abades). 
como Isidoro y Leandro de Sevilla o Fructuoso de Braga se encargaban de redactar las principales reglas y bases del monaquismo visigodo ${ }^{89}$, la condición ascética o la previa ocupación del cargo de abad se fueron convirtiendo en variables cada vez más frecuentes entre los prelados hispanogodos ${ }^{90}$.

En lo relativo a los grupos nobiliares, si bien su presencia ya quedó registrada al inicio del Concilio III de Toledo (589) entre los firmantes de la abjuración arriana ${ }^{91}$, su asistencia como miembros del officium palatinum parece que pudo institucionalizarse algunas décadas más tarde ${ }^{92}$, adquiriendo una identidad particular como miembros del Oficio Palatino en el sínodo toledano del $653^{93}$. Con la presencia de estos nobles laicos no sólo se ratificaba el creciente contacto entre Iglesia y monarquía en los concilios generales de Toledo, sino también la injerencia cada vez mayor de estos cánones en asuntos políticos y la necesidad de coordinación entre prelados y nobles seglares, con el rey a la cabeza, a fin de ejercer un gobierno eficaz y justo en las regiones peninsulares ${ }^{94}$.

El concilio VIII de Toledo supuso un hito en la politización de estas asambleas al ampliar enormemente la base de participación laica en ellas con el objetivo final de conseguir la aprobación del mayor y más representativo número de personalidades políticas y eclesiásticas del reino sobre aquellas medidas y/o sanciones que cada soberano buscara imponer por la vía legal ${ }^{95}$.

Pese a que en origen el concilio tuvo una naturaleza esencialmente eclesiástica y durante la mayor parte de su historia antigua centró su contenido normativo en asuntos de índole meramente disciplinar, durante el periodo visigodo en Hispania las reuniones conciliares se convirtieron en una forma de gobernar el territorio no sólo en materia de fe sino también en los aspectos más relevantes de la vida social, económica, política y militar de la época. En este sentido, aunque la interrelación Iglesia-Imperio ya había alcanzado un notable punto de referencia

89. Para estas reglas manejaremos la edición de J. Campos Ruiz e I. Roca Melia, San Leandro, San Isidoro y San Fructuoso. Reglas monásticas de la España visigoda, 1971.

90. Valgan los ejemplos episcopales descritos para Hispania en El De viris Illustribus de Ilde fonso de Toledo la mitad de los cuales reúnen la condición de haber sido previamente monjes o abades (ed. de C. Codoñer, 1972) o el caso de Martín de Tours para la Galia. La presencia literaria de estas figuras también ganó empaque en esta época en obras como la ya citada de Ildefonso [De Vir. Illust., III: el monje Donato (1972, pp. 120 123)], o las Vidas de los Santos Padres de Mérida [VPSE II: el monje de Cauliana; III: el abad Nancto (ed. de I. Velázquez, 2008, pp. 59 69)].

91. VIVES, J., Concilios visigóticos e hispanorromanos, 1963, p. 123.

92. Concilio IV de Toledo (633), praefatio; Concilio V de Toledo (636), praefatio.

93. Concilio VIII de Toledo (653), lista de firmantes: De los varones ilustres del oficio palatino.

94. Concilio XII de Toledo (681), tomus regius.

95. SÁNCHEZ ALBORNOZ, C., "El Aula Regia y las asambleas políticas de los Godos", Estudios visigodos, 1971, pp. 127 141; ORLANDIS, J., "Los laicos en los concilios visigodos", Anuario de historia del derecho español, nº 50, 1980, pp. 185186. 
en el Concilio de Nicea (325) y en la figura de Constantino ${ }^{96}$, fue sobre todo a partir del siglo VI cuando en Hispania la colaboración entre el poder religioso y el político se hizo plenamente efectiva al entremezclarse los intereses de ambos colectivos en la canonística conciliar ${ }^{97}$. Los que iniciaron la cuestión del intervencionismo monárquico en la esfera eclesiástica ya desde mediados del siglo VI fueron los líderes suevos. Durante su mandato se celebraron, entre otros, los dos concilios provinciales de Braga (561 y 572) (98 $^{98}$, dando origen con ello a la tradición goda posterior de convocar los concilios por iniciativa monárquica ${ }^{99}$.

A raíz de la conversión del pueblo visigodo a la fe católica, los concilios llegaron a ser un decisivo instrumento de cooperación entre el gobierno eclesiástico y el civil al servir de reconocimiento constitucional y espiritual tanto de la autoridad ejercida por los obispos en sus comunidades ("teocracia") como de la potestad regia en casi todos los ámbitos de la sociedad hispanogoda, incluyendo el eclesiástico ("cesaropapismo") ${ }^{100}$. Así, al tiempo que los monarcas de Toledo se beneficiaban del elemento eclesiástico al conferir una base teocrática a su autoridad y legitimar su proyecto político, la institución eclesiástica obtenía un gran peso civil que le permitía participar jurídicamente en la conformación de la legislación visigoda e incluso intervenir decididamente en la política del regnum ${ }^{101}$.

Los concilios de Toledo se desarrollaron, por tanto, como reuniones en las que se debatieron las más importantes cuestiones religiosas y políticas del momento y donde la unidad entre Iglesia y Estado iniciada por el monarca Recaredo alcanzó su máxima expresión pública. A partir del Concilio III de Toledo (589) los monarcas pasaron a ser la única potestad encargada de convocar y disolver los conci$\operatorname{lios}^{102}$, presentar los temas y propuestas a tratar en ellos (tomus regius ${ }^{103}$ ) y validar

96. No en vano, fue el propio emperador quien convocó y presidió el concilio, mostrando gran empeño e interés por facilitar a los obispos de todas las regiones el traslado desde sus sedes hasta el lugar de reunión (Eusebio de Cesarea, Vita Constantini, III, 6.1).

97. CASTILlO MALDONADO, P., "Concilios hispanos tardoantiguos...", 2010, pp. 417431.

98. Concilio I de Braga (561), prafeatio; Concilio II de Braga (572), praefatio.

99. ARCE, J., Esperando a los árabes. Los visigodos en Hispania (507-711), 2011, pp. 238239.

100. A pesar de que ambos conceptos teocracia y cesaropapismo han sido utilizados por parte de la historiografía moderna para definir la etapa visigoda (KING, P. D., Derecho y sociedad en el reino visigodo, 1981, pp. 42 ss.), ninguno de los dos expresa con exactitud los térmi nos reales de la asociación entre ambos poderes, pues monarquía y episcopado actuaron en común en bastantes ocasiones, pero también de manera autónoma y cada uno al margen del otro. GONZÁLEZ, T., "La iglesia desde la conversión...", 1979, pp. 432 490; MARTIN, C., La géographie du pouvoir..., 2003, pp. 191192.

101. VALVERDE, M. R., "La iglesia hispano visigoda: ¿fortalecedora o limitadora de la sobe ranía real?", Hispania Antiqua, n 16, 1992, pp. 381392.

102. Concilio III de Toledo (589), praefatio.

103. Ibídem (589), praefatio. DÍAZ Y DÍAZ, M. C., "Los discursos del rey Recaredo: El Tomus", Concilio III de Toledo, XIV Centenario (589-1989), 1991, pp. 223236. 
las disposiciones legislativas allí tomadas (lex regia in confirmatione concilii ${ }^{104}$ ). La intervención regia no se limitó al ámbito general, pues también la convocatoria de concilios provinciales dependió en buena medida de su aprobación ${ }^{105}$ y en las actas de asambleas como las de Mérida (666), Toledo XI (675) o Braga III (675) los obispos no olvidaron expresar su sincera gratitud a monarcas como Recesvinto o Wamba por la celebración de estos sínodos ${ }^{106}$.

Con el tiempo, una parte cada vez mayor de la legislación conciliar fue dirigida a tratar asuntos gubernamentales relativos al ámbito monárquico. A este respecto, si ya el concilio IV de Toledo (633) fue utilizado por el monarca Sisenando para legitimar su cuestionable ascenso al trono y garantizar la estabilidad política ${ }^{107}$, los concilios V (636) y VI (638) de Toledo dedicaron gran parte de su contenido legal a cuestiones estatales de primer orden tales como la sucesión regia, las traiciones a la corona o la salvaguarda de la familia real y de sus posesiones económicas, propósitos que fueron ocupando cada vez más espacio en la canonística toledana del siglo $\mathrm{VII}^{108}$. Por medio de la legislación conciliar, el obispo adquirió el papel de policía moral, usando la excomunión como un arma a la hora de proteger a los monarcas legítimos frente a las usurpaciones regias o a ciertas sublevaciones de nobles. Como consecuencia de ello, la monarquía visigoda tuvo que resolver algunos de sus conflictos a través de la legislación canónica y aceptar que la sucesión en el trono necesitaba también de la aprobación del correspondiente episcopado ${ }^{109}$.

Tal fue la potestad episcopal en el ámbito político a través de los concilios que en ocasiones la Iglesia llegó a participar, directa o indirectamente, en la designación de sucesores reales o incluso en la deposición de algunos sobera$\operatorname{nos}^{110}$, coincidiendo estas medidas con épocas de debilidad monárquica por el

104. Ibíd. (589). Edicto del rey en confirmación del concilio.

105. Concilio de Mérida (666), can. V y VII. La creación de la figura del executor regis (Con cilio IV de Toledo, can. III) también estuvo encaminada al control monárquico de los sínodos provinciales.

106. VIVES, J., Concilios visigóticos e hispanorromanos, 1963, pp. 325, 344345 y 378.

107. Concilio IV de Toledo (633), can. LXXV.

108. Concilio V de Toledo (636), can. II IX, Concilio VI de Toledo (638), can. XIII XIX; Con cilio VIII de Toledo (653), Decretum iudicii universalis; Lex edita in eodem concilio a Recesvinto principe namque glorioso; Concilio X de Toledo (656), can. II; Concilio de Mérida (666), can. II; Concilio XII de Toledo (681), can. I; Concilio XIII de Toledo (683), can. III V; Concilio III de Zaragoza (691), can. V; Concilio XVI de Toledo (693), praefatio y can. VIII X; Concilio XVII de Toledo (694), can. VII.

109. Concilio VIII de Toledo (653), can. X; Concilio XII de Toledo, (681), can. I.

110. Valgan los ejemplos de Suintila (Concilio IV de Toledo, 633, can. LXXV) y Wamba (Concilio XII de Toledo, 681, can. I). En general, sobre esta problemática, GALLEGO BLANCO E., "Los Concilios de Toledo y la sucesión al trono visigodo", Anuario de Hist. del Derecho Español, nº 44, 1974, pp. 723740. 
desarrollo de conjuras o traiciones a la corona ${ }^{111}$. Así se explica que la mayor continuidad en la celebración de los sínodos generales se sucediese sobre todo en periodos convulsos en los que el monarca necesitó justificar o afianzar su posición, como por ejemplo durante los reinados de Sisenando, Recesvinto, Ervigio o Egica. Por contra, una vez superadas las crisis regias, ya no sería necesario convocar de urgencia ningún concilio, por lo que en los periodos de relativa tranquilidad política la actividad sinodal fue mucho menos frecuente.

Esto no significa en ningún caso que se pueda hablar de "hierocracia" ni de una intervención decisiva de la Iglesia en materias de Estado. Para poder actuar como una legítima autoridad moral el episcopado precisó de la convocatoria previa de los sínodos por parte del rey, así como de la aprobación real para llevar a efecto las medidas allí tomadas ${ }^{112}$, unas restricciones a las que ningún prelado podía oponerse so pena de ser excomulgado ${ }^{113}$. Por ello, a pesar de que en algunos sínodos se mostraran discrepancias con respecto a determinadas actuaciones regias o que en otros se buscara condenarlas, estas quejas legislativas sólo se realizaron generalmente tras la muerte de los monarcas y por expreso deseo de sus sucesores como una manera de legitimar su ascenso al trono en oposición al régimen anterior ${ }^{114}$. El hecho de que en el concilio IV de Toledo (633) se legisle contra las traiciones a la corona al mismo tiempo que se apoya decididamente al monarca Sisenando, quien había accedido al trono dos años antes por medio de una sublevación, es buena muestra de que la opinión y actuación eclesiástica en este ámbito estaba claramente supeditada al interés del rey que gobernara en cada momento ${ }^{115}$.

Al margen del interés de la monarquía por la herramienta sinodal a la hora de legitimar sus políticas, en lo concerniente al episcopado, éste se sirvió del concilio no sólo como instrumento garante de la unidad dogmática y disciplinar sino también como base del dominio diocesano sobre el territorio en el que se asentaba su sede. Dado que el control territorial ejercido por los prelados se fundamentaba en un principio de posesión económica sobre las rentas de los

111. FERNÁNDEZ ORTIZ DE GUINEA, L., "Participación episcopal en la articulación de la vida política hispano visigoda", Studia Histórica. Historia Antigua, n 12, 1994, pp. 159162.

112. Así, bajo el mandato de Recaredo se celebró el concilio III de Toledo; bajo Sisenando el IV; Chintila convocó el V y el VI; Chindasvinto el VII; Recesvinto el VIII, IX, y X; Wamba pre sidió el XI; Ervigio el XII, XIII y XIV y, finalmente, los concilios XV, XVI y XVII fueron iniciativa regia de Egica.

113. Concilio III de Toledo (589), Edictum regis in confirmatione concilii.

114. Así por ejemplo, la invalidación de la sede episcopal de Aquis (¿Chaves?) creada por el metropolitano Esteban de Mérida bajo el mandato del rey Wamba (Concilio XII de Toledo, 681, can. IV), aunque supone el rechazo a una decisión regia, fue una condena que se llevó a efecto una vez fallecido el monarca y probablemente instada por su sucesor en el trono, Ervigio.

115. Concilio IV de Toledo (633), can. LXXV. 
edificios religiosos adscritos a su diócesis, los cánones conciliares se encargaron de definir los límites legales del dominio episcopal sobre el patrimonio eclesiástico de cada territorio. Este objetivo cobró una dimensión especial en los espacios rurales, donde el surgimiento de alternativas formas de espiritualidad cristiana y el desarrollo económico de las aristocracias fundiarias hicieron pronto necesaria la multiplicación e intensificación de los cánones destinados a determinar el radio de acción prelaticia sobre las novedosas construcciones eclesiales y monásticas privadas ${ }^{116}$.

En verdad, teniendo en cuenta que la definición de un territorio diocesano implicaba la asimilación de todas las ecclesiae, basilicae o parroquiae insertas en el área de influencia de la iglesia episcopal ${ }^{117}$, la extensión del dominio prelaticio sólo pudo mostrar una cierta uniformidad en los espacios urbanos, donde los obispos no hallaron apenas rivalidad a su potestad sobre el patrimonio eclesial. En el mundo rural, por el contrario, el control de los prelados sobre el territorio no se extendió homogéneamente y quedó en parte diluido, sobre todo en lo económico, por la presencia de otros agentes sociales: las elites locales, fundadoras de iglesias y monasterios rurales en ocasiones con patrimonios inalienables, y los eremitas, creadores impremeditados de espacios de culto, autoexcluidos de cualquier jerarquía eclesiástica y con una movilidad geográfica difícil de controlar.

Hasta qué punto la autonomía patrimonial de los monasterios tardoantiguos y, en menor medida, de las iglesias particulares ${ }^{118}$, condicionó un control más o menos efectivo del episcopado urbano sobre el espacio, en este caso rural, en el que éstos se localizaban, resulta una cuestión difícil de precisar ${ }^{119}$. Si tanto iglesias como monasterios precisaban de la autorización o consagración epis-

116. Concilio I de Orleans (511), can. XIII; Concilio III de Toledo (589), can. XIX.

117. Concilio I de Orleans (511), can. XIII: Que las basílicas permanezcan en la potestad de aquel obispo en cuyo territorio se hallan; Concilio III de Toledo (589), can. XIX: Ya que todas las cosas conforme a lo establecido antiguamente, están bajo la administración y el poder del obispo.

118. Concilio de Lérida (546), can. III; Concilio II de Braga (572), can. II; Concilio IV de Toledo (633), can. LI; Concilio VII de Toledo (646), can. IV; Concilio de Mérida (666), can. XVI.

119. Puesto que el concilio de Lérida (546, can. III) que proclama la autonomía de los bie nes cenobíticos remite a los sínodos galos de Agde (506) y Orleans (511) en materia monástica, M. Pérez Martínez [Tarraco en la Antigüedad Tardía. Cristianización y organización eclesiástica (siglos III a VIII), 2012, pp. 220 221] ha sugerido que convendría matizar mucho la indepen dencia patrimonial y jurisdiccional de los monasterios en la primera mitad del siglo VI, dada la tendencia de los concilios galos a reivindicar el monopolio episcopal en aspectos como las ven tas efectuadas por los abades [Concilio de Agde, (506), can. LVI]. Sólo así se entiende que a pesar de que la independencia patrimonial de los monasterios ya hubiese sido instituida en el siglo $\mathrm{V}$ al otorgarles el ius possessionis sobre los bienes de clérigos y monjes (CTh. V.3.1.), ésta tuviese que seguir siendo recordada a finales del siglo VII en una ley de Wamba del año 675 (Lex Visigot. IV.5.6; MGH. Legum Sectio, t. I, 1902, pp. 204 205). 
copal, así como de una regla interna dictaminada por los prelados en el caso de los cenobios para poder funcionar como tales ${ }^{120}$, eso significa que la potestad real sobre ellos recaería por completo en los prelados, puesto que se antoja extraño que un obispo diera permiso para fundar un espacio de culto si no fuera a ejercer un control último de autoridad sobre él desde la distancia ${ }^{121}$.

\subsection{La sede episcopal}

Si la asamblea conciliar se configuró como el principal instrumento de toma de decisiones por parte de los obispos al frente de las ciudades, el lugar desde el que ejercieron ese liderazgo hacia su territorio diocesano fue la sede episcopal, en cuya representación los prelados de cada ciudad debían acudir a los concilios provinciales y generales.

Aunque la existencia de obispados en Hispania ya estuviese constatada por lo menos desde el siglo III d. C. ${ }^{122}$, fue a partir de la consolidación del cristianismo en la Península a lo largo de la siguiente centuria cuando las iglesias y las sedes prelaticias fueron evolucionando paulatinamente de ser meras residencias episcopales a entidades de índole administrativo desde donde emanaba el poder primero religioso y después político del obispo sobre su grey y hacia toda la demarcación diocesana.

El ámbito a partir del cual se ejercía la jurisdicción diocesana vino determinado por la ciuitas o urbs, como centro de irradiación de las ideas cristianas y residencia del prelado, y por el conjunto de suburbia que circundaban al núcleo urbano y formaban su territorium ${ }^{123}$. El obispo fue durante los primeros siglos de expansión cristiana el jefe de la iglesia local, es decir, el pastor de una comunidad cuyos miembros residían en su mayoría en un ámbito urbano. Las primeras iglesias cristianas estuvieron durante largo tiempo compuestas por

120. Concilio I de Orleans (511), can. XV; Concilio de Lérida (546), can. III; Concilio de Tours (567) can. VII; Concilio IV de Toledo (633), can. LI.

121. El estudio del balance entre las competencias y reservas de los prelados y la nobleza laica sobre las iglesias rurales y los monasterios (sean o no de fundación ascética) precisaría de un desarrollo mucho mayor que el someramente aquí expuesto, por lo que reservo su análisis para futuras publicaciones.

122. TEJA, R., "La carta 67 de S. Cipriano a las comunidades cristianas de León Astorga y Mérida: algunos problemas y soluciones", Antigüedad y Cristianismo, n 7, 1990, pp. 115124.

123. El canon II del Concilio II de Sevilla (619), relativo a la disputa entre Fulgencio de Écija y Honorio de Córdoba por la jurisdicción sobre una iglesia, o el canon VIII del concilio de Méri da (666), referente al litigio territorial entre Sclúa de Idanha y Justo de Salamanca, reflejan per fectamente la coincidencia entre los límites de cada diócesis y los del territorio de cada ciudad, una asimilación que ya nada tenía que ver con la antigua división conventual de época altoim perial. SOTOMAYOR, M., "Términos de la organización territorial eclesiástica en los concilios hispano romanos y visigodos", Mélanges de l'Antiquité Tardive, Studiola in honorem Natalis Duval, 2004, pp. 288289. 
comunidades exclusivamente urbanas y era dentro de la urbs donde se desarroIlaba toda la acción gubernamental del obispo ${ }^{124}$. Cuando a partir del siglo IV el cristianismo rebase las periferias urbanas para extenderse por el espacio rural, surgirá entonces la noción de diócesis con objeto de delimitar el distrito territorial sobre el que habría de extenderse la autoridad de un determinado obispo.

En cada diócesis el obispo era la máxima autoridad, si bien esta jefatura no era ejercida de manera autónoma dentro de la provincia al tener siempre que rendir cuentas de su actuación ante el prelado metropolitano. El núcleo físico que funcionó como sede episcopal estaba compuesto generalmente por el palacio o residencia episcopal, la iglesia-catedral, gobernada de manera directa por el obispo, y un número indefinido de iglesias y basílicas menores, de advocaciones generalmente martiriales y regidas por personal eclesiástico específico pero dependiente siempre del obispado, que conformaban en su conjunto el espacio diocesano. Junto a estas iglesias en algunos casos podía emplazarse una serie de edificios anexos de funcionalidades desde litúrgicas y caritativas hasta jurídicas, monásticas o simplemente habitacionales.

El principio fundamental del gobierno episcopal en la provincia fue la estabilidad de la organización diocesana, para lo cual era indispensable que un único prelado residiera y gobernase en una sola sede, aquella para la que había sido ordenado, durante toda su vida. Quedaban así terminantemente prohibidos los traslados y estancias prelaticias en urbes o diócesis ajenas ${ }^{125}$, aun en periodos de sede vacante ${ }^{126}$. Aunque tradicionalmente la elección de un obispo estaba basada en el acuerdo entre los obispos comprovincianos, el clero de la iglesia afectada y el pueblo ${ }^{127}$, desde el siglo IV las jerarquías eclesiásticas fueron distanciando al pueblo de la participación en este proceso y concentrando el poder de decisión ordenatoria en sus manos. No obstante, el ferviente deseo de ocupación del cargo, unido a la corrupción del propio estamento episcopal, provocó con el tiempo que el acceso al episcopado no se desarrollase en términos estrictamente legales y pudiera sucederse mediante la compraventa del cargo, por coerción o, sobre todo, a través de la designación de un sucesor por parte del propio obispo en fun-

124. También pudo haber primigenias comunidades religiosas lideradas por presbíteros, a tenor del elevado número de ellos entre los asistentes al concilio de Elvira a comienzos del siglo IV.

125. Concilio de Nicea (325), can. XV XVI; Concilio de Antioquía (341), can. III, XIII y XXI XXII; Concilio de Sárdica (343), can. I III y XIV XV y XVIII XXI; Concilio de Constantinopla (381), can. II III; Concilio de Cartago III (397), can. XXXVII XXXVIII; Concilio de Calcedonia (451), can. V y XX. Para la Galia, Concilio de Orange (441), can. VIII X; Concilio de Tours (461), can. IX; Concilio de Orleans II (538), can. XVI XVII; Concilio de Arverne (535), can. VIII IX; Concilio de Arverne II (549), can. V y XIV. En Hispania, Concilio de Braga II, Capitula Martini (572), can. V VII y XII.

126. Concilio II de Braga, Capitula Martini (572), can. IX y XI, salvo excepciones (can. X).

127. TEJA, R., “¿Populus et Plebs? La participación del pueblo en las elecciones episcopales del cristianismo primitivo (siglos II III)", Popolo e potere nel mondo antico, 2005, pp. 233.247. 
ciones en ese momento (adlectio) ${ }^{128}$. La ocupación vitalicia del cargo episcopal reforzó la autoridad del prelado en cada sede y su atractivo liderazgo acabó derivando en la designación sucesoria del cargo episcopal y en el traspaso hereditario de los poderes eclesiásticos de padres a hijos o entre miembros de una misma familia (hermanos), dando origen así a la formación de dinastías episcopales como la de los Valerios en Zaragoza o los Sabinos en Sevilla ${ }^{129}$.

A nivel interno, por el contrario, la dirección y el control efectivos de la diócesis exigían que el obispo llevara a cabo visitas pastorales anuales entre las distintas iglesias que conformaban el territorio diocesano a fin de vigilar el correcto cumplimiento de la doctrina cristiana por parte de los ministros en sus respectivos templos y garantizar que todos ellos se conservasen en buen estado ${ }^{130}$. A través de estas visitas espirituales, el obispo ejercía asimismo un control económico sobre los templos adscritos a su diócesis, procurando determinar en cada "inspección" el estado físico de las iglesias o el correcto desempeño del ministerio eclesiástico en ellas, al mismo tiempo que revisaba también la recaudación de las rentas eclesiásticas o el inventario de las donaciones ${ }^{131}$.

La consecución de este dominio no fue, sin embargo, algo tan simple como la progresiva acumulación de patrimonio arquitectónico religioso presente en un núcleo urbano y sus alrededores. La construcción de una estructura diocesana durante la época tardoantigua supuso, por el contrario, un complejo y largo proceso de concienciación territorial por parte de los líderes eclesiásticos que hubo de precisar además de una unidad doctrinal de signo católico en clara sintonía con el poder político imperante, así como de una adecuación e integración de la clásica estructuración administrativa civil a las nuevas necesidades e intereses de una sociedad jerarquizada ${ }^{132}$. Esta supeditación de las jurisdicciones eclesiásticas a las fronteras seculares, sin embargo, no es tan evidente como se ha pretendido o al menos no se produjo de manera automática ni pacífica. La confusa y ambigua terminología relativa al dominio territorial eclesiástico o

128. TORRES PRIETO, J. M., "Corrupción en las elecciones episcopales durante la Antigüe dad Tardía", La corrupción en el mundo romano, 2008, pp. 265276.

129. MAÑARICUA, A. E. de, "El nombramiento de obispos en la España visigótica y musul mana", Scriptorium Victoriense, $n^{\circ} 13,1966$, p. 93; TEJA, R., "Las dinastías episcopales en la Hispania tardorromana", Cassiodorus, n 1, 1995, pp. 29 39; TEJA, R., Emperadores, obispos... , 1999, pp. 135 146; FUENTES HINOJO, P., "Sucesión dinástica y legitimidad episcopal en la Mérida visigoda", En la España Medieval, n 35, 2012, pp. 1133.

130. Concilio de Tarragona (516), can. VIII; Concilio II de Braga (572), can. I y II; Concilio IV de Toledo (633), can. XXXVI; Concilio XVI de Toledo (693), can. V.

131. VILLALUENGA, S., "El control del patrimonio eclesiástico: inspecciones y censura de cuentas en la iglesia de Toledo", Pecunia, no 14, 2012, pp. 56.

132. DÍAZ MARTÍNEZ, P. C., "Sedes episcopales y organización administrativa en la cuenca del Duero (siglos IV VII)", De Roma a los bárbaros: poder central y horizontes en la cuenca del Duero, 2008, pp.123 124. 
la propia indefinición de la territorialidad civil hispana en época bajoimperial -ise mantuvieron las antiguas demarcaciones prerromanas? ${ }^{133}$, ¿se eliminó la división conventual de época augustea? ${ }^{134}$ - dificultan mucho poder realizar cualquier generalización al respecto ${ }^{135}$. Por otro lado, el hecho de que las invasiones germanas del siglo $\mathrm{V}$ rompieran con la estabilidad territorial y alteraran las fronteras de los espacios diocesanos o que las disputas entre los obispados por el control efectivo de un núcleo eclesiástico y del territorio adscrito a él se convirtieran en leitmotiv de la canonística conciliar hispanorromana y visigótica demuestran que la formación de una geografía eclesiástica en esta época fue un proceso complejo y no exento de conflictos.

El estudio de la geografía eclesiástica hispana reviste, por tanto, de una notable complejidad ya incluso desde su propia concepción, tanto por el renovado significado religioso que cobraron ahora algunos términos propios de las antiguas demarcaciones territoriales civiles (territorium, provincia, conuentus, dioecesis, etc.) como sobre todo por las diferentes definiciones que recibió el territorio bajo jurisdicción eclesiástica.

En este sentido, el término empleado comúnmente para designar al conjunto de espacios físicos bajo dominio eclesiástico fue el de "diócesis", un concepto de origen griego (dioikesis = administración de la casa) aplicado en derecho romano al territorio dependiente de una ciudad. Este vocablo, sin embargo, sólo fue empleado regularmente con una acepción territorial en la zona oriental del Imperio ${ }^{136}$, resultando más complejo discernir su significado preciso en la canonística hispanorromana y visigoda. En líneas generales, el término dioecesis adaptado a la geografía eclesiástica procede de la reforma administrativa llevada a cabo por Diocleciano a finales del siglo III d. C. con el objetivo de ordenar territorialmente las provincias del Bajo Imperio. Dicha reforma consistió en subdividir las provincias altoimperiales en unidades territoriales menores, pero a su vez comprendidas en circunscripciones más amplias, Ilamadas diócesis.

133. GARCÍA GONZÁLEZ, J. J., "Valpuesta y su entorno en épocas tardoantigua y protome dieval", Estudios mirandeses, no 24, 2004, p. 171.

134. Concilio I de Toledo (397 400), praefatio; Concilio de Lérida (546) praefatio; Concilio IV de Toledo (633), can. XXV y LIII.

135. GURT, J., RIPOLL, G. y GODOY, C., "Topografía de la Antigüedad tardía hispánica. Reflexiones para una propuesta de trabajo", Antiquité Tardive, n 2, 1994, pp. 164 169; RIPOLL, G. (et alii), "La arquitectura religiosa hispánica del siglo IV al X y el proyecto del Corpus Archi tecturae Religiosae Europeae CARE Hispania", Hortus Artium Medievalium, vol. 18, n 1, 2012, pp. 4647.

136. Concilio de Constantinopla (381), can. II. En el mundo oriental el concepto de diócesis se aplicaba, no obstante, a enormes extensiones territoriales que englobaban a varias provincias eclesiásticas metropolitanas bajo el control de un exarca. 
En el caso de la Península Ibérica, la división provincial tripartita propuesta por Augusto (27 a. C.) -Baetica, Lusitania y Tarraconensis-, evolucionó en tiempos de Diocleciano (298 d. C.) hacia la conformación de un total de seis provincias -Gallaecia, Tarraconensis, Lusitania, Carthaginensis, Baetica y Mauritania Tingitana-, siete a partir de los reinados de Valentiniano y de Valente (364-378) con la inclusión de las Insulae Baleares, englobadas todas ellas bajo la denominación común de dioecesis Hispaniarum ${ }^{137}$. Esta lista no incluye ni a Carpetania y Celtiberia ${ }^{138}$ ni a Cantabria ${ }^{139}$ como supuestas provincias hispanas, ya que aunque así sean designadas en algunas fuentes de la época, todo apunta a su consideración más bien como regiones dentro de sus provincias ${ }^{140}$.

Pese a lo complejo del proceso contamos con varias y reconocidas fuentes que permiten aproximarnos al desarrollo de la división provincial de Hispania. Éstas son el Laterculus Veronensis (¿312?), el Breviarium de Rufo Festo (369), la Cosmographia de Julio Honorio (376), la Notitia Dignitatum, en concreto la parte de la Notitia Occidentis (398-400), el lulii Honorii Cosmographia (segunda mitad del siglo IV) y el Laterculus Provinciarum de Polemio Silvio (449). Aunque todos estos documentos se muestran incompletos, imprecisos cronológicamente y de validez informativa desigual -los dos últimos son quienes incluyen a las Baleares como provincia única-, en conjunto dan una idea general de la estructuración administrativa de la Península Ibérica a lo largo del siglo IV. Esta composición pervivió durante los siglos de dominio visigodo y todo apunta a que sirvió además como base para la posterior organización eclesiástica tardoantigua.

A raíz de la asunción más o menos real de la ordenación administrativa por el lenguaje y la praxis eclesiástica, las comunidades religiosas fueron jerarquizándose y agrupándose bajo la supervisión general de un obispo. Si bien en las primeras etapas de expansión cristiana tal vez no sea posible hablar aún de sedes episcopales o de espacios diocesanos ${ }^{141}$, sino más bien de pequeñas colectividades religiosas en torno a una iglesia, las nuevas necesidades organizativas y la creciente ambición económica de los prelados hicieron pronto necesaria la am-

137. Notita Dignitatum III.6; XXI.7 (aquí se especifica que la Bética, la Lusitania y la Galecia eran provincias consulares, mientras que la Tarraconense, la Cartaginense, la Tingitana y las Baleares eran provincias praesides). ALBERTINI, E., Les divisions administratives de l'Espagne romaine, 1923; ARCE MARTÍNEZ, J., El último siglo de la España romana: 284-409, 2009, pp. 43 82; NEIRA, C., La Notitia Dignitatum. Nueva edición crítica y comentario histórico, 2005.

138. Concilio II de Toledo (527), Carta del obispo Montano a Toribio; Concilio III de Toledo (589) firmas episcopales: Eufemio, en nombre de Cristo, obispo metropolitano de la iglesia católica de Toledo de la provincia Carpetana. Gregorio de Tours, Historia Francorum, VI, 33 y 44 . Ed. de B. Krusch y W. Levison, MGH Scriptores Rerum Merovingicarum, I, 1 1951, pp. 304 y 316.

139. Juan de Bíclaro, Chronicon, 32, a. 574. Ed. de C. Cardelle y R. Collins, 2001, p. 66.

140. MARTIN, C., La géographie du pouvoir..., 2003, pp. 7282.

141. La primera mención escrita en la que el término diócesis aparece asociado a unos pará metros eclesiásticos fue recogida en el código Teodosiano allá por el año 376. CTh. XVI, 2, 23. 
pliación de los límites jurisdiccionales de cada comunidad eclesiástica y los espacios religiosos bajo dominio prelaticio comenzaron a adquirir un carácter espacial. El obispo ya no sólo presidía una comunidad local en representación de la Iglesia universal, sino que además estaba al frente de un territorio, con su clero y sus iglesias, y dirigía la vida cristiana dentro de los límites de aquél.

Este cambio en la concepción del espacio religioso también es detectable a nivel lingüístico en la literatura conciliar, pues en los sínodos anteriores a la segunda mitad del siglo VI fue habitual, aunque no excluyente, que no se especificara el nombre de la sede de la que el prelado firmante era titular ${ }^{142}$, mientras que a partir del Concilio II de Braga (572) se generalizó la colocación del genitivo ecclesiae y el nombre de la ciudad a la que representaba el obispo en las firmas conciliares. Esto significaría que aunque en los primeros sínodos los prelados hispanos actuaron en nombre de la Iglesia de Dios en general, ya desde el siglo VI cada prelado acudió a estas asambleas como líder de un espacio concreto, adquiriendo la dignidad episcopal un marcado componente territorial ${ }^{143}$.

En verdad, pese a que la propia imprecisión de la terminología administrativo-eclesial no permite fijar una territorialidad concreta para los espacios eclesiásticos ${ }^{144}$, lo cierto es que la retórica conciliar tardoantigua fue ampliamente explícita en lo que a la asociación entre obispos y términos geográficos se refiere. Conceptos como ecclesia ${ }^{145}$, sedis $^{146}$, dioecesis o parrochia ${ }^{147}$ se fueron alternando a lo largo del siglo VII con otros como conuentus, prouincia, confinitimus o territorium ${ }^{148}$, determinantes de un lenguaje administrativo civil y de una cierta

142. Concilio I de Toledo (400); Concilio de Gerona (517); Concilio II de Toledo (527); Con cilio I de Barcelona (540); Concilio de Lérida (546); Concilio de Valencia (549); Concilio I de Braga (561).

143. SÁNCHEZ SALOR, E., Jerarquías eclesiásticas y monacales en época visigótica, 1976, pp. 2122.

144. Por ello, algunos autores prefieren hacer uso del término genérico de "distrito eclesiás tico" a la hora de referirse a los espacios religiosos en esta época como una forma de no cate gorizar aquello de lo que no se está seguro. VIVES, J., "Nuevas diócesis visigodas ante la invasión bizantina", Spanische Forschungen, no 17, 1961, pp. 8 9; GURT, J., RIPOLL, G. y GODOY, C., "Topografía de la Antigüedad tardía...", 1994, pp. 164169.

145. Concilio de Braga II (572) y III (675); Concilio de Toledo III (589), IV (633), V (636), VI (638), VII (646) y XI (675); Concilio de Sevilla I (590) y II (619); Concilio II de Barcelona (599).

146. Concilios X (656), XII (681), XV (688) y XVI de Toledo (693) y Concilio de Mérida (666).

147. En esta época los términos parrocia y dioecesis se emplean indistintamente como sinó nimos, es decir, territorios pertenecientes o administrados por el obispo. RIPOLL, G. y VELÁZ QUEZ, I., "Origen y desarrollo de las parrochiae en la Hispania de la Antigüedad Tardía", Alle origini della parrochia rurale (IV-VIII sec.): atti della giornata tematica dei Seminari di Archeologia Cristiana (École Française de Rome, 19 marzo 1998), 1999, pp. 111121.

148. Concilio IV de Toledo (633), can. XXXV y LIII; Concilio VI de Toledo (636), can. VII; Concilio VII de Toledo (646), can. V; Concilio XI de Toledo (675), can. II. 
adscripción territorial a su persona ${ }^{149}$. La utilización de toda esta terminología confirmaría que ya desde época visigoda es posible hablar de una geografía eclesiástica hispana, si bien heterogénea y en proceso de consolidación.

Las primeras noticias firmes en torno a la extensión de la presencia episcopal en Hispania datan de comienzos del siglo IV (Concilio de Elvira) y describen una presencia prelaticia aún poco densa (no más de 70 sedes) en comparación con el número de sedes existentes en Galia (117), África (800) o Italia (250) ${ }^{150}$ y desigualmente distribuida por la Península, constatándose en el sur una tupida red de obispados frente a una menor densidad en el norte, coincidente sólo con las principales ciudades de la época.

Con posterioridad al sínodo iliberritano, la imprecisión e irregularidad de las actas conciliares anteriores al siglo VI nos impiden conocer con seguridad el número exacto de sedes episcopales existentes en Hispania a comienzos de la quinta centuria, así como sus propios límites diocesanos, a lo que tampoco ayuda el hecho de que las invasiones germanas alterasen probablemente las fronteras territoriales y eclesiásticas peninsulares.

Dada la conflictiva situación creada por el trasiego de pueblos y ejércitos que sufrió casi toda la franja norte peninsular a mediados del siglo $\mathrm{V}$, con el añadido de la bagaudia para la Tarraconense, es de suponer que de existir fronteras diocesanas, éstas hubieron de modificarse al fluctuar los destinos de las ciudades, sedes y diócesis en función del dominio mayor o menor de uno u otro pueblo invasor en cada región. Así, por ejemplo, en el sur peninsular parte de la provincia Bética -las diócesis de Malaca, Iliberris, Corduba, Egabrum y Assidona- quedó englobada junto al Levante (Cartaginense) bajo el dominio bizantino hasta su progresiva liberación entre los siglos VI y VII por parte de los visigodos ${ }^{151}$. Éste pudo ser también el caso de la provincia Cartaginense al quedar dividida en una zona controlada por los bizantinos (Celtiberia) y otra bajo dominio visigodo (Carpetania). Esta escisión no duró demasiado, pues tras la expulsión de los bizantinos durante la primera mitad del siglo VII ambas regiones quedaron asimiladas dentro de la Cartaginense y bajo la potestad episcopal de Toledo ${ }^{152}$.

El problema de las escisiones territoriales y eclesiásticas por el avance germano fue especialmente acusado en la región noroccidental de la Península Ibérica,

149. DÍAZ MARTíNEZ, P. C., "Propiedad y poder. La iglesia lusitana en el siglo VII", Cuadernos emeritenses, $n^{\circ} 10,1995$, p. 55. No en vano en el lenguaje jurídico de las Leges Visigothorum los términos más asociados al obispo no fueron los de ecclesia, parochia o dioecesis, sino los de locus, civitas y territorium.

150. PRIETO, M., Los obispos hispanos a fines del Imperio..., 1994, pp. 120121.

151. RIPOLL, G., "Acerca de la supuesta frontera entre el Regnum Visigothorum y la Hispania bizantina", Pyrenae, n 27, 1996, pp. 251267 (mapa de extensión bizantina en p. 262).

152. VIVES, J., “Nuevas diócesis visigodas...", 1961, pp. 89. 
pues aquí los suevos, a consecuencia de su prolongada ocupación, dividieron eclesiásticamente la provincia Gallaecia en una doble metrópoli ${ }^{153}$ y mantuvieron una pugna constante con el pueblo visigodo por el control de la zona, Ilegando a alterarse con ello los confines de las provincias lusitana y galaica ${ }^{154}$.

Con la extensión del dominio godo por toda Hispania, una vez anexionado el reino suevo en el 585 y expulsados los bizantinos de sus territorios peninsulares entre los años 621 y $625^{155}$, el reino de Toledo se configuró eclesiásticamente tomando como base el conjunto de provincias bajoimperiales, ahora restauradas (Tarraconensis, Baetica, Lusitania, Cartaghinensis y Gallaecia), con la inclusión de la Narbonense tras la disolución de reino visigodo de Tolosa (507) ${ }^{156}$. En el territorio suevo, tras la anexión de su reino a los dominios visigodos en el 585 se restablecieron los límites de las antiguas provincias romanas de Lusitania y Gallaecia y se eligió una única sede, la de Braga, como metropolitana de esta última provincia. Por su parte, con la toma de Cartagena por los visigodos en el año 624, todo vestigio de "provincialidad" bizantina desapareció y la Cartaginense recuperó su territorio, cediendo, eso sí, el rango de metrópoli a Toledo ${ }^{157}$.

La Hispania de los siglos VI y VII vivió, por tanto, una etapa de gran vitalidad eclesiástica en la que las sedes episcopales preexistentes ampliaron su prestigio social y su poderío económico, centralizando algunas de ellas ciertas manifestaciones culturales y extendiendo su influencia por extensos distritos rurales. Por su parte, nuevos obispados fueron surgiendo a lo largo del territorio hispano y no siempre vinculados a espacios urbanos, lo que da una idea del enorme prestigio de la figura episcopal en esta época y de la importancia de la sede prelaticia como expresión tanto de liderazgo ideológico como de dominio territorial. Esta eclosión del fenómeno episcopal quedaría reflejado en el amplio registro prelaticio que recogió el concilio III de Toledo (67 sedes) [Fig. 2], en cuyo caso habría que incluir asimismo a las sedes que se hallaran vacantes durante su celebración $\mathrm{o}$ a las que no pudieron asistir por los avatares políticos del momento ${ }^{158}$.

153. Concilio II de Braga (572), praefatio.

154. Concilio de Mérida (666), can. VIII. LÓPEZ QUIROGA, J. y BANGO GARCíA, C., "Los edificios de culto como elemento morfogenético de transformación y configuración del paisaje rural en la Gallaecia y en la Lusitania entre los siglos IV y IX", Cuadernos de Prehistoria y Arqueología de la Universidad Autónoma de Madrid, no 31 32, 2005 2006, pp. 3235.

155. Isidoro de Sevilla, Historia Gothorum, 49 y 62 (ed. de C. Rodríguez Alonso, 1975).

156. GRIFFE, E., La Gaule chrétienne a l'époque romaine. I. Des origines chrétiennes a la fin du IVe siècle, 1964, pp. 332340.

157. MANSILLA, D., "Orígenes de la organización metropolitana en la iglesia española", Hispania Sacra, no 12, 1959, pp. 275290.

158. Para la Gallaecia y el norte de Lusitania contamos además con el Parroquiale Suevum (s. VI). DÍAZ MARTíNEZ, P. C., "EI Parrochiale Suevum: organización eclesiástica, poder político y poblamiento en la Gallaecia Tardoantigua", Homenaje a José María Blázquez, vol. 6, 1998, pp. 3548. 
Si bien con el reino de Toledo se unificaron los territorios físicos bajo un mismo signo político y la jurisdicción de cada obispado hubo de acomodarse a la antigua trama administrativa bajoimperial, la creciente ambición territorial prelaticia, el interés regio por controlar zonas conflictivas, amén de las propias vicisitudes de la época, provocaron numerosas alteraciones en la geografía eclesiástica hispana, tanto por la reducción en la jurisdicción de los episcopados más antiguos como por la toma de conciencia de sus límites por parte de las nuevas sedes. Es en estos momentos cuando se desarrollaron con más fuerza las reclamaciones y disputas territoriales entre obispos a razones de cercanía geográfica y de tradición administrativa entre obispados de diferentes provincias $^{159}$, de división de espacios diocesanos por conflictos bélicos ${ }^{160}$, de ubicación de iglesias en la frontera entre diócesis ${ }^{161}$ o de reintegración de límites entre provincias $^{162}$. Todas estas peticiones contaron con el respaldo legislativo siempre y cuando se realizaran dentro del marco de una misma provincia y no entre distintos espacios provinciales ${ }^{163}$.

El mapa episcopal que dibujan las fuentes conciliares de esta época [Fig. 2], en definitiva, no engloba ya únicamente a centros de prolongada trayectoria urbanística ni tampoco vincula a los espacios prelaticios con núcleos de un rango jurídico específico. La elevación de un espacio físico a la categoría de obispado respondía ahora a múltiples variables y a particulares evoluciones que en muchos casos resultan difíciles de analizar y catalogar ${ }^{164}$. No resulta extraño, por ello, que incluso a finales del siglo VII se siga legislando en relación al surgimiento de nuevas sedes episcopales y se trate de frenar su creación en entornos "donde nunca antes hubo un obispo" ${ }^{\prime 165}$. El hecho de que algunos de estos obispados encontrasen además importantes trabas en su expansión por los espacios rurales ante el desarrollo de alternativas formas religiosas y de nuevos competidores en el dominio del patrimonio eclesiástico supone una dificultad añadida a la hora de fijar límites diocesanos precisos a la acción prelaticia desde las ciudades.

Como consecuencia de esta compleja situación, la historiografía sólo ha podido describir para este periodo unas territorialidades eclesiásticas poco o nada precisas ${ }^{166}$ y una multiforme evolución del paisaje eclesiástico de cada

159. MARTIN, C., "Las cartas de Montano y la autonomía episcopal de la Hispania septen trional en el siglo VI", Hispania Antiqua, n 22, 1998, pp. 403426.

160. Concilio II de Sevilla (619), can. I.

161. Concilio II de Sevilla (619), can. II.

162. Concilio de Mérida (666), can. VIII.

163. Concilio IV de Toledo (633), can. XXXIV.

164. GURT, J. M. y SÁNCHEZ RAMOS, I., "Episcopal groups in Hispania", Oxford Journal of Archaelogy, no 30 (3), 2011, p. 277.

165. Concilio XII de Toledo (681) can. IV.

166. MARTíN VISO, I., "Organización episcopal y poder entre la Antigüedad tardía y el medievo (siglos V XI): las sedes de Calahorra, Oca y Osma", Iberia, n 2, 1999, p. 164; MOU 


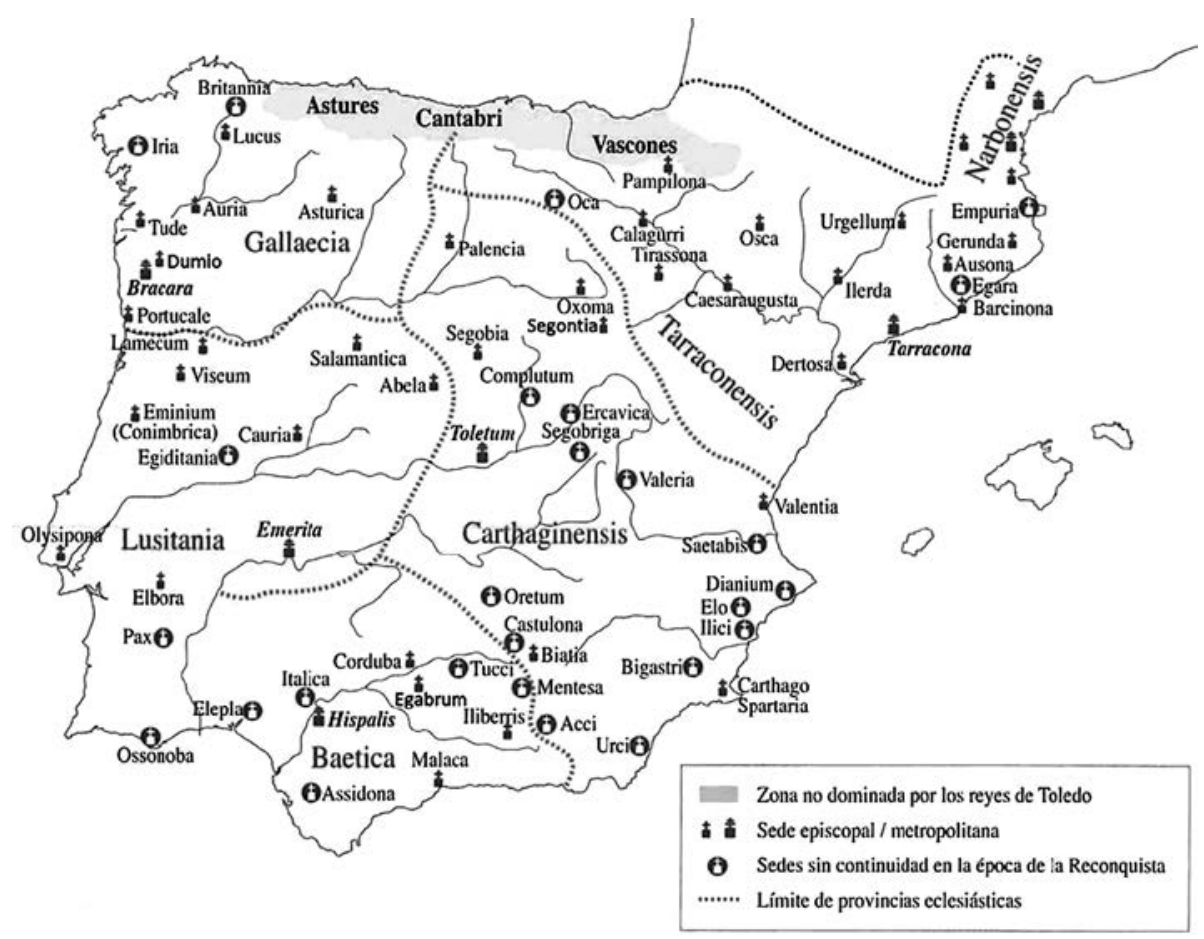

Figura 2. Provincias eclesiásticas y sus sedes episcopales en la Hispania de finales del siglo VI d. C. (MONSALVO, J. M., 2010).

provincia, lo que en unos casos dio origen a nuevas sedes en espacios de escasa tradición cristiana ${ }^{167}$ y en otros eliminó todo rastro de episcopalidad en territorios de insuficiente peso demográfico ${ }^{168}$.

\section{Conclusiones}

Al margen las distintas vicisitudes por las que pasó la formación de las diócesis hispanas, lo cierto es que los obispos, haciendo uso del aparato conciliar

NIER, M. B., "Centres urbains et évolutions de l'organisation spatiale en Rioja de l'Antiquité tar dive à la fin de sa reconquête (IVe XIle siècles)", Villes et campagnes de la Tarraconaise et d'alAndalus (Vle-XIe siècles): la transition, 2007, pp. 225226.

167. VIVES, J., "Nuevas diócesis visigodas...", 1961, pp. 1 9; DÍAZ MARTíNEZ, P. C., "EI Parrochiale Suevum...", 1998, pp. 3547.

168. LORING, M. I., "La difusión del cristianismo en los medios rurales de la Península Ibérica a fines del Imperio romano", Studia Historica. Historia Antigua, no 4 5, 1986 87, pp. 200201. 
y de la sede episcopal como herramienta y órgano de gobierno respectivamente, Ilevaron a cabo toda una nueva organización del espacio y de las relaciones interprovinciales a través de la legitimación sinodal y el poder jurisdiccional que confería la territorialidad diocesana sobre la que se extendía el dominio prelaticio. Se configuró así un nuevo paisaje geopolítico en Hispania basado en unas novedosas coordenadas eclesiásticas que delimitaron desde ese momento las relaciones de poder tanto dentro como fuera de cada región.

La reorganización provincial surgida a partir del siglo VI fue, no obstante, fruto del nuevo equilibrio de influencias en la Península Ibérica entre el poder político godo, que delimitó las fronteras físicas aproximativas entre provincias, y el poder territorial de los obispos, quienes, en virtud de su liderazgo eclesiástico y del dominio ejercido desde sus respectivas sedes, buscaron extender el control diocesano sobre zonas de presumible vacío pastoral. En este sentido, la creciente intervención de las monarquías germánicas en la vida religiosa peninsular supuso que tras la unificación toledana el soberano se convirtiera en un importante activo en la articulación eclesiástica del territorio desde el momento en el que cada elección episcopal, cada celebración sinodal o cada medida allí tomada habían de ser supervisadas y ratificadas por el monarca de turno.

La intervención de la esfera política en la vida religiosa del regnum no fue, con todo, la única limitación que encontró el ente prelaticio a la hora de actuar libremente en su territorio. La expansión y diversificación del cristianismo por el vasto territorium imperial hizo necesario, al igual que sucedía a nivel administrativo, establecer un reparto de competencias eclesiásticas con el doble objetivo de hacer llegar y hacer cumplir a toda la población el mensaje cristiano. A un nivel jurídico, la necesidad de establecer medidas y actuaciones en común entre los diferentes obispos, ya fuese en reuniones provinciales o nacionales, implicaba en sí misma la concepción de una autoridad global superior a la del prelado local. De este modo, inspirándose en el modelo político y social de la época, se desarrolló toda una organización piramidal del episcopado en cuya base se hallaban los obispos sufragáneos de cada provincia al mando de una sede o diócesis, que correspondía generalmente con una urbe. Por encima de ellos se situaron los obispos metropolitanos, supervisando la actuación de los sufragáneos y liderando el panorama eclesiástico a nivel provincial. Con la consolidación del reino hispanogodo con capital en Toledo, esta sede regia fue centralizando la vida religiosa de la Península y ya desde el siglo VII las metrópolis provinciales fueron perdiendo gran relevancia eclesiástica en beneficio del primado toledano, un obispado que acabó adquiriendo una categoría suprametropolitana en la jerarquía prelaticia hispana. En el vértice de la pirámide eclesiástica se situaría el patriarca de Roma, como máxima autoridad religiosa en Occidente. Éste, a pesar de su escasa participación en la vida eclesiástica de la Hispania visigoda, dominó claramente el horizonte religioso occidental entre los siglos IV y VI. 
En el proceso de consolidación del poder territorial del obispado, por tanto, no sólo hay que tener en consideración el uso de herramientas como la asamblea sinodal o la sede prelaticia sino también la propia estructuración jerárquica del episcopado. Dada la extensión territorial del cristianismo y las necesidades pastorales de cada espacio, la actuación eclesiástica tuvo que diversificarse necesariamente desde lo más particular, delegando el gobierno de cada iglesia a presbíteros, diáconos o a clérigos en general, hasta lo más universal, quedando así subordinados todos los prelados sufragáneos y metropolitanos de cada provincia a la autoridad del obispo de Roma. Esta organización eclesiástica hubo de condicionar de alguna manera la extensión efectiva de cualquiera de las diócesis, por lo que todo estudio sobre la articulación eclesiástica del territorio hispano no puede entenderse sino a partir del análisis de este jerarquizado organigrama episcopal. Pero eso es tema para otro estudio aparte. 